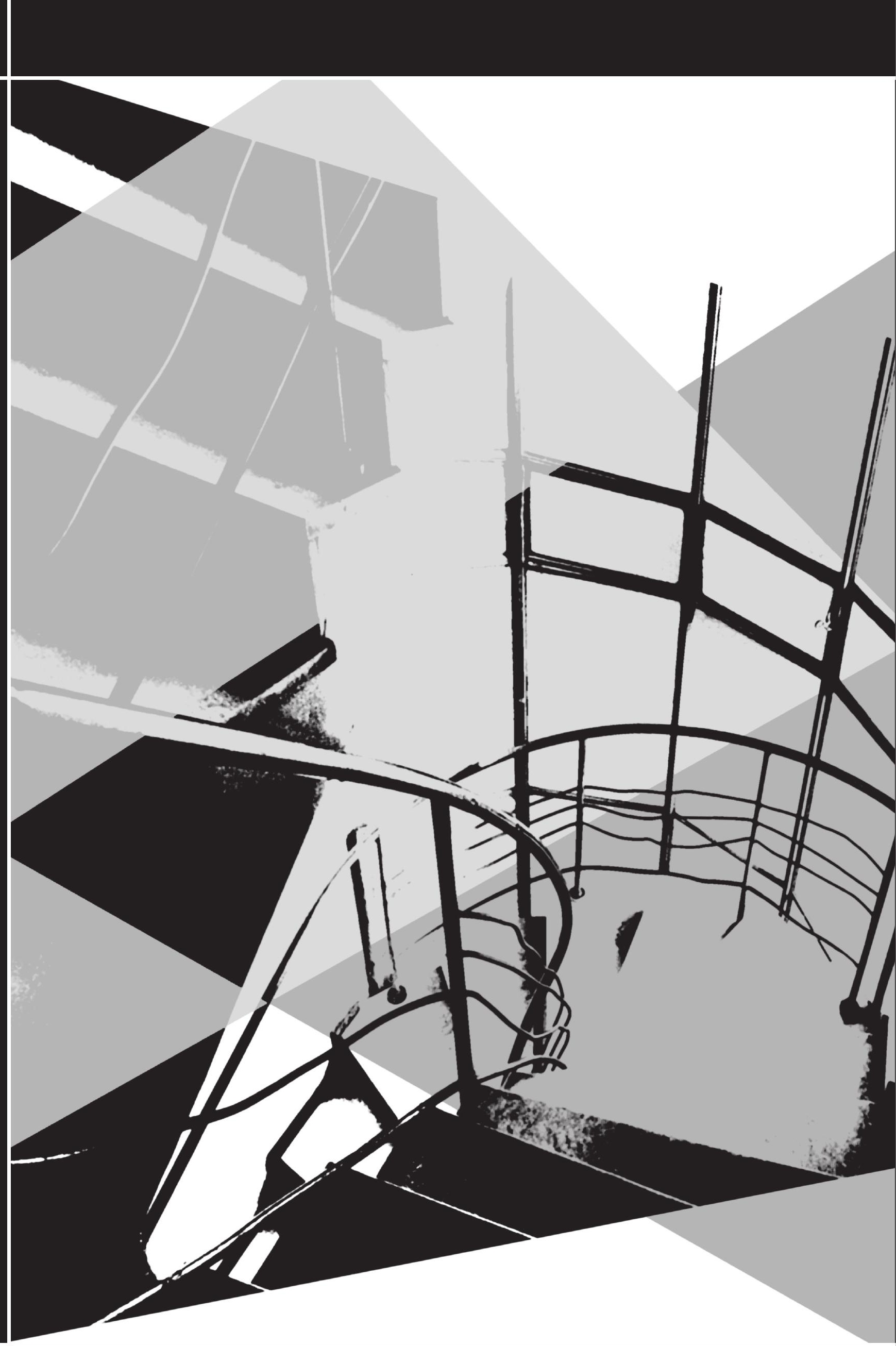


MARIA VICENTINA DE PAULA DO AMARAL DICK

\section{A língua}

de São Paulo

MARIA VICENTINA DE

PAULA DO AMARAL

DICK é professora do

Departamento de Letras

Clássicas e Vernáculas da

FFLCH-USP. 


\section{A FUNDAÇÃO DE PIRATININGA}

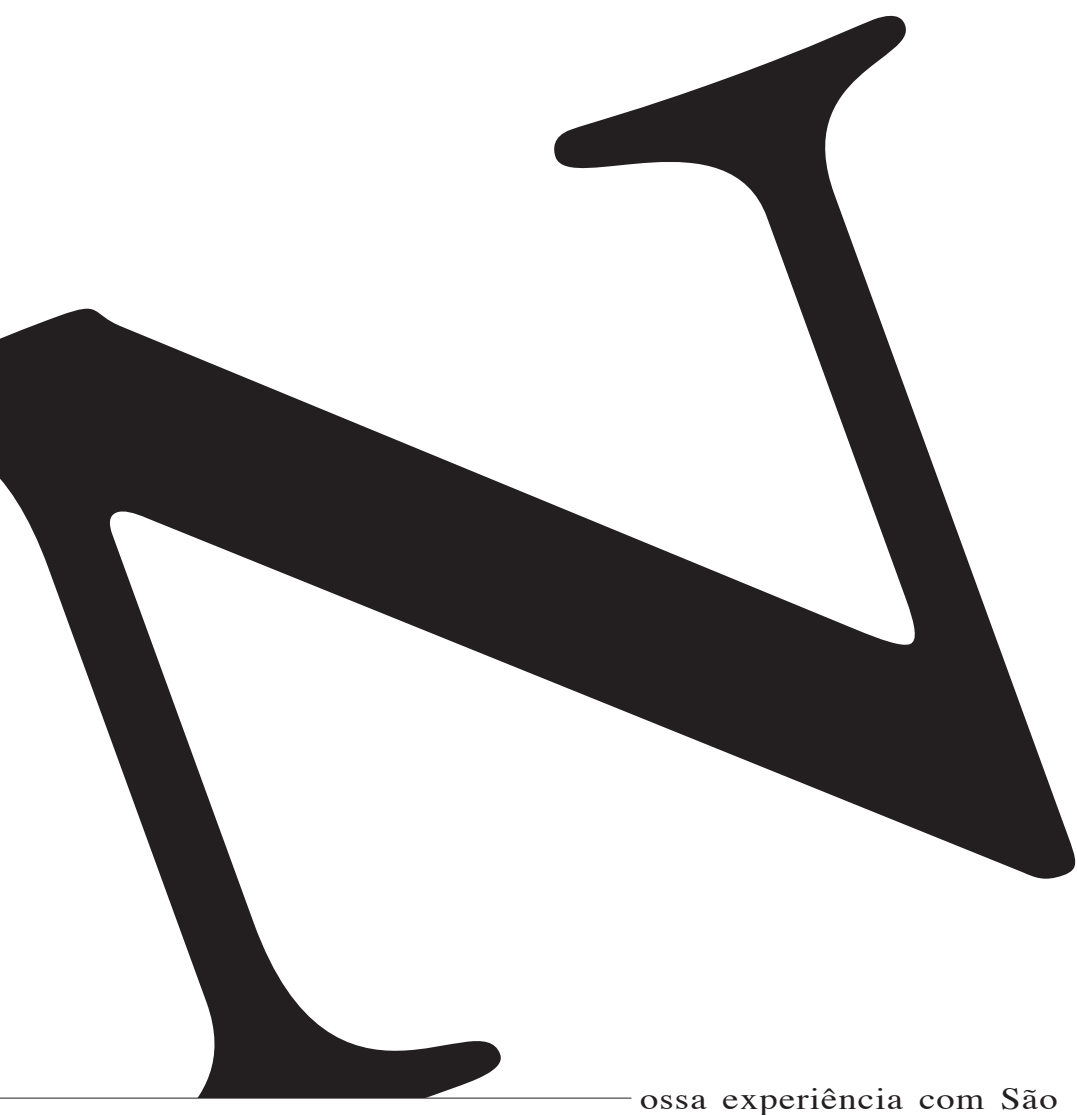

Paulo, quando a escolhemos, já há algum tempo (1988) (1), como um objeto ou modelo possível para os estudos toponímicos em grandes áreas individualizadas, ultrapassa o dado temporal para recuar até a concepção de uma imagem mais idealizada e distinta do objeto concreto conhecido.

Como comunidade social e lingüística, São Paulo excede, em muito, qualquer perspectiva de estudo dirigida a um ponto determinado, quase sempre desviando o pesquisador da rota traçada, tanto os meios que se cruzam, enovelando-o nos seus propósitos mais palpáveis. Isso ocorre porque, por detrás de tudo, paira sempre a imagem inverossímil do que era e do como é hoje, à maneira de um ser anímico. Essa tensão é criada pela dialética do supostamente inatingível (Dick, 1997) que parece assim continuar sendo, por mais que se o reconstitua, como fizemos em uma perspectiva determinada, de acordo com uma metodologia também determinada. Na ocasião, para “apreender” São Paulo, como dissemos, partimos do não-nome e do nome para chegar ao não-lugar e ao lugar, este, resultado daquele, só atingindo uma individualidade depois ou a partir de quando recebesse um designativo. O espaço, portanto, que iria se tornar vila, depois cidade, ganharia uma projeção no real ao receber a denominação; esta seria, para nós, o traço condutor de sua individualidade, tornando o recorte mais ou menos significativo conforme o nome evoluísse, paulatinamente, do campo cognitivo para permear o plano afetivo do sentir e do querer. Só aí aquela porção espacial deixaria de ser o nada para tornar-se um indicativo do fazer concreto da população, um constructo não apenas léxico-terminológico, mas um referencial sígnico daquele grupo, transformado em marcador simbólico das suas características físicas e emocionais. Emprestamos, assim, ao nome a capacidade plena e totalizante de representar o concreto e o imaterial, pelo poder evocativo da memória.

Parafraseando Lynch (1976, p. 87), entendemos que "una ciudad es una organización cambiante y de múltiplos propósitos, una tienda para muchas funciones, levantada por muchas manos y con relativa velocidad. [...] Laforma tiene que ser algo libre de trabas, plastica, en relación con los objetivos y las percepciones de sus ciudadanos". Além disso, porém, há funções fundamentais expressivas das formas de cidade: "la circulación, los principales usos de la tierra [...]; las esperanzas y los placeres colectivos, el sentido comunitário [...]. Por sobretodo, si se organiza en forma visible el medio ambiente y se lo identifica nitidamente, el ciudadano, puede impartirle sus proprios significados y conexiones. Entonces se convertirá en un verdaderolugar, notable e inconfundible", um lugar-próprio da comunidade.

Lingüisticamente, as cidades e as regiões podem ser conhecidas e identificadas de dois modos práticos: pelo seu designativo ou pelo seu nome toponomástico e pela sua posição ou situação no espaço geográfico regional. Priorizamos mais, como traço identitário e significativo, o nome dado ao núcleo original ou o nome 
resultante das modificações administrativas por que passou, povoado, freguesia, vila, distrito, município-sede. Valorizamos o nome como um verdadeiro marcador existencial, aquilo que confere ao lugar personalidade jurídico-administrativa capaz e pertinente. Mas um lugar ou uma cidade nãoé apenas isso.É também memória afetiva, responsável pelas raízes individuais e coletivas da população. Só quando existe esse reconhecimento do pensar pluralizadoé que o núcleo se torna uma comunidade etnolingüística, com suas crenças, seus valores ideológicos, seus símbolos, sua história. Sem esses vínculos, será apenas um ajuntamento de pessoas, que desconhece o sentido do ethos grupal, de sua ascendência e de seus representantes eponímicos. Por isso a consideração que se empresta ao chamado centro de uma cidade, também conhecido como centro histórico e, em alguns lugares, centro velho. Todas essas explicações, na realidade, são parassinônimos de um único evento: o local onde surgiu o povoado e de onde saíram e para onde convergiam os traçados dos caminhos antigos, os seus pontos de ligação com o mundo exterior, extramuros, como se diz.

Mesmo incipiente, a então Vila de São Paulo do Campo, chamada também de Vila de Piratininga ou Piratininga simplesmente, teria os seus marcadores simbólicos pelos quais se tornaria conhecida ou que reconheceria como próprios. O marcador social, como o consideramos, é o recorte lingüístico identificador de elementos do espaço habitado, que se tornam recorrentes no cotidiano do lugar, sejam de natureza física ou noológica. Nos textos escritos, quando existem, surgem sempre como um princípio ordenador da vida comunitária, muitas vezes ou por serem únicos no meio, ou por terem importância vital para os moradores, ou por serem pontos sagrados ou míticos, ou por necessitarem deles para circulação diária. Essa identificação lingüística muito simples, no início, é suficiente para a constituição de um quadro comunicativo e também toponomástico, podendo permanecer, indeterminadamente, apesar da expansão do núcleo, ou sofrer alterações na estrutura morfológica dos termos empregados, gerando outros designativos e outras formas de dizeres. Quando isso ocorre, a mudança na vocabularização, por consequiência do próprio discurso intencional, que acaba incorporando outras formas de designação que não a tradicional, cria uma nova mensagem, que pode levar a um vácuo designativo pela tensão do uso nome antigo/novo nome, até a fixação do recente pela substituição da designação anterior. Às vezes, e isso é freqüente, ocorre o que chamamos de paralelismo denominativo, utilização de duas dessas formas de tratamento para um mesmo objeto, até que um se apague do inventário onomástico, podendo permanecer ou não, ocasionalmente, como mero resíduo de alguns formantes iniciais expressamente ou apenas na memória histórica: Santa Cruz das Almas; Cruz das Almas (São Paulo, bairro e rua). Os denominativos primários, Sítio do Bom Sucesso, Sítio das Araras, Capela Nova, Capela Nova de Araras, Samambaia, dos quais o primeiro apareceu por volta de 1863, fundiram-se todos num só, sob a invocação da antiga padroeira Nossa Senhora do Patrocínio das Araras, retirado do Ribeirão das Araras, que acabou prevalecendo na escolha final do município, Araras, simplesmente.

As populações de um modo geral, em qualquer meio em que se situem, interpretam-no, como já anotamos, de duas maneiras: ou objetivamente, retratando-o conforme suas conveniências ou necessidades, de um modo direto, descritivo, ou emocionalmente, enfatizando características mais sensitivas que perceptivas; é o caso das homenagens, dos sentimentos, dos estados anímicos, espiritualizados, voltados às crenças, à devoção, à fé mística.

O discurso dos camaristas nas Atas da Câmara da Vila do Campo, no período colonial, reproduz essas circunstâncias na narrativa dos fatos, deixando claro como a população se orientava e se movimentava no espaço que já se prenunciava urbano na segunda metade do século XVII. Na sessão de 31 de janeiro de 1660, a Câmara da vila, em presença do ouvidor geral, deliberou 
no sentido de se refazer os caminhos da vila e o caminho do mar, de vital importância para a sobrevivência econômica do planalto, repartindo as tarefas entre os homens bons do campo, capitão Fernão Dias Pais, capitão Joseph Ortis de Camargo, capitão João Pais e outros. "Fernão Dias, com sua gente, faria o caminho desde o rio pequeno até o cume da serra"; o capitão Ortis de Camargo "se obrigava e tomava a seu cargo fazer o dito caminho desde o rio grande até o rio pequeno com a gente de quauqraïya [caucaia?]" e "reparando as pontes que lhe toquar". O capitão João Pais, com “a gente de virapueira e virapuranga [hoje Ibirapuera e Ibiraporanga - pau bonito/ou ibirapiranga, pau vermelho], desde a borda do campo [antigo Santo André, desaparecido depois] até o rio Grande [Tietê] em companhia de anrique da cunha llobo e francisquo corea de llemos com toda a gente de quaguasu [caaguasu, 'mato grande', atual zona da Avenida Paulista] até São Miguel [São Miguel de Ururaí, próximo, hoje, à área do atual São Miguel Paulista]”. Tudo "sob pena do pagamento de seis mil réis [...] pera as despezas do dito caminho", pelo descumprimento da ordem.

Essas transcrições nos inserem, diretamente, no contexto discursivo da época, mostrando, de um lado, a retórica autoritária dos camaristas, em nome de Sua Majestade, e, do outro, a subserviência aos princípios da Igreja, "movidos do zello que tem do serviço de $\mathrm{D}^{\mathrm{s}}$ e do dito Senhor [Sua Majestade, o rei de Portugal] tudo, porém, a ser feito por uma causa nobre, o bem comum do [deste] povo".

Os topônimos paulistanos citados mostram a situação híbrida da língua falada no campo,na segunda metade do século XVII, no contínuo retratado desde 1554, e documentado nos designativos que ainda permanecem, contemporaneamente, apesar de a língua nativa, então utilizada, ter caído em desuso desde o Setecentos.

Durante dois séculos, portanto, houve uma intensa atividade de comunicação entre os dois sistemas de fala existentes no planalto, que resultou, primeiro, numa situação de dois sistemas em isolamento. Todos eram monolíngües. O contato da população nativa com a alógena gerou, de início, um bilingüismo assimétrico, de ambos os lados, depois um bilingüismo simétrico, para o retorno ao monolingüismo, e o desaparecimento do sistema de menor prestígio. No caso paulistano, desapareceram a sociedade nativa e seus membros e, com eles, a língua que falavam, acarretando a permanência de apenas um dos sistemas, tornado a língua padrão de São Paulo. Os resíduos lingüísticos do sistema desaparecido permaneceram, ainda, em vitalidade, por algum tempo, até sua extinção do uso cotidiano. Traços lexicais, porém, continuaram na língua de chegada, presentes apenas na toponomástica, mas passíveis ainda de estudo. Isso porque, em nossa concepção, o modelo toponímico utilizado em qualquer região é o mesmo da língua falada, as unidades terminológicas de um são recortadas do outro, de seu quadro de ocorrências vocabulares.

Examinando-se Atas da Câmara do século XIX, a fim de se confrontar a exemplos extraídos das Atas de 1877, nota-se uma situação lingüística ou línguo-toponímica um pouco diferente daquela retratada. Excetuando-se os dois ribeiros centrais, cujos topônimos se mantiveram,o Tamanduateí e o Anhangabaú, e o próprio Tietê, além dos ribeirões da Mooca e do Aricanduva que começam a ser citados, até mesmo por uma questão de coerência urbana, a partir do século XIX, os subúrbios da banda oriental da cidade começam a surgir, recebendo novos nomes e alargando-se, assim, os limites de São Paulo para a parte leste, com uma nova feição. Nesse ano, 1877 (Atas, LXIII), firmam-se os nomes portugueses nas ruas, distritos e acidentes da zona central da cidade, mantendo-se uma tendência que já registramos, anteriormente, a saber: Distritos da Paróquia da Sé, Santa Iphigenia, Consolação, do Ó, do Braz, Penha de França; Largo 7 de Setembro, Praça do Mercado, Ponte dos Lázaros, Ponte da Travessa do Seminário, Bica do Miguel Carlos, Largo da Liberdade, Ruas da Glória, dos Estudantes, Largo do Pelourinho, Rua do Gasômetro, Rua do 
Doutor João Theodoro, Rua da Conceição, no bairro da Luz, Rua e Várzea do Carmo, Rua de Santa Tereza, Rua do Quartel, Ponte do Meio na Várzea do Carmo, Rua do Bom Retiro na "freguesia de Santa Iphigenia", Rua do Ouvidor, Largo da Misericórdia, Largo do Pelourinho, Rua do Rozario...

É preciso lembrar, porém, que a retomada dos termos indígenas na cidade ocorreu no final do século XIX e início do XX, impulsionada por outros fatores sociais representados pela própria expansão urbana e consequiente adensamento populacional fora do centro, o antigo e o expandido, para além do Campo do Chá. O que se deve, em muito, à consolidação de novos bairros Higienópolis, Pacaembu, Perdizes, de um lado; Mooca, Tatuapé, Pary (Pari), Belém/ Belenzinho até a Penha, do outro. Na primeira década do século XX, surgem os bairros-jardim, a oeste da cidade, na zona que era considerada o sertão, no século XVI, com abertura de novas ruas e vias de acesso, ensejando motivações novas na comunicação (visão eurocêntrica) e recuperando traços lingüísticos desaparecidos com a perda da fala índia.

Na ata examinada (Atas, LXIII), são poucos, porém, os topônimos tupis no espaço urbano oitocentista, alguns já existentes como caminhos, conservando o mesmo nome; outros, abertos em função de um novo recorte do terreno, valendo-se dos mesmos nomes dos córregos e ribeirões, prolongados nos bairros e, depois , nas ruas melhoradas, como na Rua de Tabatingüera (antigo caminho), Rua da Mooca (tendo o rio como referencial), Rua do Pary, Ladeira do Acu (antigo caminhoe baixada, no início da atual Avenida São João, com Rua São Bento, significando, pelo étimo, var.de Yacuba - “água quente, saloba"e, por extensão, “água venenosa"). Não se trata, por certo, de criações de novas formas de língua mas aproveitamento e conservação das antigas conhecidas, existentes no espaço da vila. Uma exceção, como significante introduzido,é a Rua dos Guaianazes, nos Campos Elíseos, que passa a integrar, nessa época, o inventário le- xical disponível, a partir do designativo do grupo indígena do planalto. As formas indígenas citadas indicam uma tipologia nomeadora que denominamos "translação toponímica", significando o deslocamento de um vocábulo em uso onomástico emuma área para outro acidente próximo, consolidando um bloco de ocorrências locais. Esse fenômeno lingüístico, hoje, tornou-se comum na cidade de São Paulo, sendo empregado para vários fins, inclusive como protótipo de marca significativa.

Dentro desse conjunto de fatos lingüísticos que caracterizaram os dois sistemas de comunicação do planalto, a ata de 31 de janeiro de 1660, utilizada como exemplificação, ganha em importância quando se destacam, do texto, as modalidades axiológicas ou valorativas presentes no espaço urbano paulista e que condicionavam o comportamento social da vila. Completase o quadro discutido com as seguintes ponderações:

a) o espaço da Vila de São Paulo era um espaço de ação ou espaço de fazer, que deveria gerar um constructo objetivo - recuperar o caminho do mar-e um constructo subjetivo - demonstrar a importância dos capitães paulistanos ou da elite do pequeno burgo seiscentista, cada um com sua gente, numa relação de domínio e de obediência;

b) o espaço da vila comportava símbolos-ideais dentro de um imaginário católico-romano;

c) o espaço da vila tomava como limites do fazer marcadores de natureza física: caminhos terrestres e rios que recortavam o terreno;

d) o espaço útil da vila, sendo pequeno, dispensava nomes específicos ou topônimos propriamente ditos para alguns de seus acidentes referidos nos discursos dos camaristas que utilizavam, nesses casos, termos genéricos seguidos de adjetivos determinativos de suas dimensões: "rio grande", "rio pequeno"; ou de sua posição geográfica: "cume da serra”, "borda do campo", "serra acima";

e) o espaço da vila recortava à maneira da língua tupi os núcleos habitados, como se citou: "virapueira", "virapuranga", 
“quaguasu”, “quauqraíya”, “juquery” (bairro do) (termo de vereação de 8/11/1660);

f) o espaço da vila recortava suas porções discriminativas usando os templos religiosos como pontos de referência: "até São Miguel”; "na matriz"; "desde o Canto até São Bento"; “de São Bento até São Francisquo”; “de São Francisquo até o Carmo"; "na matriz e no Carmo"; "no Colégio".

De certa forma, esse circuito assim demarcado era o centro da vila, desde o final do Quinhentos, quando as ordens religiosas começaram a se estabelecer no planalto, os franciscanos chegando um pouco depois,noSeiscentos. Esclareça-se que, por "Canto", está subentendido o topônimo nuclear da vila, conhecido como "os quatro cantos". Na toponímia atual, recobre o traçado quadrangular da Praça do Patriarca, seguindo em reta até o Mosteiro de São Bento, antiga Colina de Inhapuambuçu ("campo arredondado [alto] grande").

De acordo com os tópicos mencionados (de $a$ a f), os símbolos paulistanos seiscentistas, representados em objetos perceptíveis, com contornos definidos, evidenciam-se no discurso dos camaristas, como, por exemplo, os acidentes hidrográficos principais da vila, numa relação opositiva:

a) o rio grande e o rio pequeno, que significam dois rios sem nomes (quando têm, na realidade) pela imprecisão da citação, para quem é estranho ao lugar;

b) o acidente orográfico identificado por “cume da serra", que traduz, na expressão nominal, a familiaridade dos moradores com sua geomorfologia, dispensando qualquer outra forma de chamamento, por desnecessária ao grupo;

c) as igrejas da vila, cada uma com seu santo padroeiro, cujos territórios de atuação são bem demarcados pela extensão da devoção.

Pode-se concluir, assim, estas considerações retomando Lynch na referência ao recorte ambiental: "los actos de diferenciar y modelar el medio ambiente pueden constituir una base para la ordenación del comodimiento [...] el paisaje desempeña una función social. El medio ambiente con sus denominaciones, familiar para todos, proporciona material para recuerdos y símbolos comunes que ligan al grupo y le permiten comunicarse entre sus miembros. El paisaje actúa como un vasto sistema mnemotécnico para la retención de la historia y dos ideales colectivos. [...] La organización simbólica del paisaje puede contribuir a aliviar el medio, a estabelecer una relación emocionalmente segura entre dos seres humanos y su medio ambiente total" (Lynch, 1976, p. 149)

Não se quer dizer com isso, ou seja, com a transcrição imediata de pontos do pensamento do autor que, particularmente, se privilegie uma rígida orientação ambientalista para o estudo do meio. É bom lembrar que, ao analisarmos a toponímia da cidade de São Paulo, do ponto de vista de seus dois centros históricos (Dick, 1997, p. 23), ficou claro que a pesquisa se estruturava em um só plano de trabalho, definido, genericamente, como A TERRA. Em torno dela, como uma personagem metafórica e animizada, competente para comandar todos os atos e atitudes dos homens que para cá vieram, foi que agrupamos as análises da nomenclatura toponímica do planalto consolidadora da civilização aqui implantada.

\section{A POPULAÇ̃̃O INDÍGENA E OS ALDEAMENTOS DA VILA DO CAMPO}

Estudar a população indígena de São Paulo do Campo, sua distribuição areal, seja no planalto ou no país como um todo, assim como a localização de seus aldeamentos, o modo como vivia, é ponto extremo de um longo processo de aquisição e perda de valores, de mistura étnica e cultural, de extinção e desaparecimento dessas sociedades, de morte, guerras, destruição, mas também de renascimento.

Dentre esses complicadores para uma análise pragmática e funcional do problema, que dificultam a perspectiva de uma abordagem menos racionalizante, nota-se que a história dos índios de São Paulo é a 
própria história dos indígenas da costa brasileira, da época pré-cabralina até os primeiros contatos.

São dois momentos diferenciados, mas que têm pontos em comum: no primeiro deles, movimentos contínuos de migrações internas, dos mesmos grupos ou de grupos diferentes, buscando, simbolicamente, mitos telúricos, difundidos pelos guaranis de São Vicente, vindos de seus pontos de difusão, a sudoeste, e que outras hordas também incorporaram. Onde, porém, ficaria a "terra sem males"? Pela rota do deslocamento, estaria na linha acima do Equador, sempre em subida, se considerarmos a entrada desses índios pelas bandas da Bacia do Prata. Com sua passagem, alterariam a configuração dos ocupantes do próprio meio e, pelo seu espírito guerreiro, a valorização das guerras. Daí o aparente contraditório: buscavam a "boa terra", a ybymarã-e ỹn, sem frio, sem fome, até mesmo sem lutas, mas, para conquistá-la, enfrentavam todos esses perigos, da longa travessia sem volta. Daí o significado mítico dessa busca, do inatingível.

A América de Colombo, porém, já conhecera esses movimentos guerreiros de sujeição e mesmo de expulsão dos primitivos habitantes. Talvez esse fato explique a presença de tupinambás ao norte do país no Madeira, a dez léguas de sua embocadura, conhecido pelo nome de Tupinambarana, ou furo dos Abacaxis. Marcoy (1858-59), que refez a viagem de Pedro Teixeira (1619) pelo Amazonas, relata que nesse canal (Tupinambarana ou Abacaxis) por onde o Madeira e o Amazonas se comunicam, havia "remanescentes" dos tupis ou tupinambás, encontrados pelos portugueses ao chegarem ao Pará na margem direita do baixo Amazonas (Marcoy, 2001, p. 200). Ressalta, também, a índole guerreira desses índios, que só cederiam à dominação européia depois de muita resistência, o que levou o autor a algumas análises comparativas aos guaranis: “Os Tupinambá desapareceram há dois séculos do Brasil, mas o seu idioma tornou-se a língua corrente em duas ou três províncias do Império, notadamente na do Pará” (Marcoy,
2001, p. 201). Traçando o roteiro desses índios, encontra a língua sendo falada por grupos dos Andes bolivianos, aí localizados desde séculos anteriores, como os chiriguanos do Paraguai. A conclusão natural foi que tupis e guaranis formariam, no início, um só povo que depois se separou, "por força de circunstâncias locais" (loc cit.), o que a lingüística moderna comprovou com segurança. Geograficamente, os antigos tupis, por esse relato, ocupariam a parte mais medieval da América, com vestígios no Paraguai, no Chaco argentino, chegando ao Brasil, onde se localizavam na serra de Ibiapaba, nas províncias do Pará, Maranhão, Pernambuco e Bahia. Uma parte do grupo esteve no Rio Beni (século XVIII), o que será indício possível dos resíduos lingüísticos encontrados, no chamado nheengatu.

No "Roteiro Geral da Costa Brasileira", parte introdutória do Tratado Descritivo do Brasil, em 1587, Gabriel Soares de Souza (1971) apresenta a relação dos grupos existentes no Quinhentos, a partir do Rio das Amazonas até a ponta do Rio da Prata, "além da bacia de São Matias". Identifica-os por seções areais, tomando como limites separatistas ora os rios, ora cabos, portos, baías, capitanias, povoações, entremeando os nomes dos grupos às formas específicas de reconhecimentos, a saber: "Vida e costume do gentio potiguar", "quem são os caetês", "quem são os aimorés", "quem são os tupiniquins", "quem são os goitacases", "quem são os papanases", "quem é o gentio tamoio", "quem são os guaianases", “costumes dos carijós”. Esses os grupos do Brasil quinhentista, nomes quase lendários que a toponímia brasileira procura manter vivos, enquanto os estuda do ponto de vista etnolingüístico. A eles, soma-se o grupo tupinambá, já citado, que Gabriel trata separadamente, em um capítulo especial, a "Notícia Etnográfica do Gentio Tupinambá que Povoava a Bahía", indicando, desse modo, o tratamento diferenciado dado ao grupo povoador da região.

Comparando-se essa localização com a descrita por Paul Marcoy (2001), já se tem dois focos de dispersão desse povo, um, ao 
norte, no Maranhão; outro, mais ao nordeste, na Bahia. A lingüística indígena atual aponta um terceiro subgrupo, localizado no Rio de Janeiro, perfazendo, portanto, um total de três variações dialetais da mesma língua. Ainda, no “Título 18” do Tratado, completa o inventário étnico com referências a outras nações vizinhas da Bahia, nem todas da família tupi-guarani, como os tupinaẽ, amoipiras e outros grupos chamados tapuias, à época, entre os quais estão os ubirajaras, "senhores dos paus", que "se não entendem nas linguagens com outra nenhuma nação do gentio" (Souza, 1971, p. 336); os maracás do rio de São Francisco, além de outros que correm "toda esta terra do Brasil”, "de diferentes costas, com mui diferentes costumes, e são contrários uns dos outros; se fazem guerras muitas vezes e se matam sem nenhuma piedade" (Souza, 1971, p. 341).

Da relação apresentada por Gabriel respeita a este trabalho o reconhecimento de alguns dos grupos constantes, os tupiniquins, localizados do Rio Cricaré ao Doce, no Espírito Santo; os goitacás e papanás, do Porto Seguro ao Espírito Santo; os tamoios, do Rio de Janeiro a Angra dos Reis; os guaianás, de Angra dos Reis até Cananea; depois de São Vicente, estão os carijós, em constante guerra com os guaianás, "matando-se uns aos outros cruelmente, inclusive com os tamoio".

Este, portanto, o quadro populacional americano (ou um dos que foram apresentados no período descritivo do meio e das línguas faladas) em que São Paulo se situava no século XVI, imerso em grupos conflitantes entre si, tanto na costa como sertão adentro. Beirando o mar de São Vicente, desde Martim Afonso assim chamado, estavam os índios costeiros, na rota de Angra dos Reis, antes Angra dos Reis Magos, até a barra da Bertioga e a ilha de Santo Amaro. Eram os tamoios de Gabriel, que não menciona os tupiniquins, até o Rio de Cananea; ao contrário, insiste na referência de "que é o gentio tamoio de que tanto falamos", justificando mencioná-los nesse ponto do litoral do Rio a Angra, mais especificamente "do rio do cabo de São
Tomé”, “do qual limite foram lançados para o sertão, onde agora vivem”, contrários de todos os gentios, “senão dos tupinambá, de quem se fazem parentes”. Com eles se entendem lingüisticamente (tupinambás e tamoios), pois tinham "fala" parecida. Seriam, assim, amigos, pela práxis da época, mas, pela parte de São Vicente, na costa, eram inimigos dos goitacás; de "outra parte" de São Vicente, guerreavam com os guaianás, continuamente. Por serem mais organizados que os tupinambás, diz ainda Gabriel que esses tamoios tiveram grande entrada com os franceses, bem recebidos no Cabo Frio e no Rio de Janeiro, “onde os deixaram fortificar em vila até que o governador Mem de Sá os foi lançar fora”. Na mesma zona, dava-se o comércio do paubrasil, se é que se pode falar dessa forma, em função da época, uma vez que o autor diz: "costumavam resgatar cada ano mil quintais de pau-brasil aonde carregavam muitas naus que traziam para a França". Apesar de não ser adequado, para o momento histórico vivido, utilizar-se da expressão "comércio clandestino ou ilegal" - porque a situação administrativa da colônia ainda era precária, pela instalação recente -, o fato é que esses episódios de parceria entre grupos aparentemente antagônicos causavam perturbação social. A extensão do território costeiro era um dos motivos para essa instabilidade na defesa dos domínios portugueses na América. Mas em uma outra relação configurada por situações diferentes, a história indígena de São Paulo caracteriza o segundo momento da historiografia autóctone, em sua formação.

Mais no interior da capitania, estrategicamente situada no alto da colina de Inhapuambuçu, até São Bento, a vila também conhecida como Piratininga ( $p i r a ́$, peixe, tininga, seco, a secar) dependia para fins econômicos da barra de São Vicente, em cujo ponto mais distante situava-se a Vila de Nossa Senhora da Conceição de Itanhaém (itá, pedra, nhaẽen, vasilha)e, do outro, o porto de Santos, a Ilha de Santo Amaro ou de Guayó (caranguejo), duas léguas depois, a barra de Bertioga (casa; refúgio da tainha). No limite sul litorâneo, 
estendia-se até Cananea. Gabriel refere-se à vila desta maneira: "nove léguas sertão adentro, geralmente chamada $O$ campo". Essa forma de dizer não era estranha a Portugal, documentos antigos registram “oporto", “obispo", “ailha”, com o artigo unido à palavra que precisa. Pobre, a vila, possuía a casa dos inacianos, além de quatro aldeias de índios cristianizados. Os índios paulistas, caracteristicamente, eram os guaianás que Anchieta reparte em guaianá do campo e do mato, estabelecendo, assim, um quadro opositivo que, antes de ser terminológico, era etnocultural: “Não sabem pelejar entre o mato, senão no campo onde vivem, em rixas constantes com os tamoios vizinhos. Mas deles diferiam porque habitavam no campo, em covas pelo chão, debaixo do chão". Do ponto de vista da língua, o cronista diz ser diferente da dos índios fronteiriços, embora se entendessem com os carijós, além de São Vicente. Mas não há menção de entendimento com outros grupos, muito embora os citados no Tratado como habitantes da costa pertencessem à mesma família lingüística.

De um modo geral, porém, a língua (tupi antigo) já estava disseminada, nessa época da fundação de São Paulo e da sua consolidação como vila, não apenas no planalto propriamente dito, mas em suas cercanias, fora do burgo. Os aldeamentos indígenas estabelecidos na entrada do sertão para a vila e desta em direção ao caminho do Rio, ou seja, de Parnaíba (a oeste) até Nossa Senhora da Escada (a leste), foram responsáveis pelo início e manutenção do novo sistema híbrido português-tupi na fala do povo, pelo menos até meados do século XVIII.

Nos primeiros anos do Quinhentos, após a fundação de São Paulo, os aldeamentos eram de responsabilidade dos inacianos, que chegaram com os colonos (1549). Em 1580, como resultado dos embates dos índios entre si, dos portugueses do planalto e dos guaianás de Tibiriçá e Caiubi, contrários aos liderados por Piquerobi, ocorreu a primeira repartição espacial desses grupos, feita por Anchieta, em território paulista. Uma parte permaneceu no que veio a ser o aldeamento de Nossa Senhora da Conceição dos Pinheiros, a oeste, outra parte transferiu-se para Ururaí, depois São Miguel de Ururaí, e outra constituiu o aldeamento de Nossa Senhora da Conceição dos Guaru, depois Guarulhos. Petrone (1995) analisou esses agrupamentos, doze ao todo, resultantes da ação jesuítica, os mais antigos sendo mais próximos da zona central da vila, ou da zona litorânea. Formavam núcleos denominados pelo autor de "aldeamentos do círculo de São Paulo”, a saber, Pinheiros (1580), São Miguel (1592; em 1583 , era a aldeia de Ururaí), Barueri (1612), Embu (1615), Guaru (Guarulhos, 1580), Itapecerica e Carapicuíba (século XVII). Fora de São Paulo, o de Nossa Senhora da Escada (século XVII), Nossa Senhora da Ajuda de Itaquaquecetuba (século XVII), São José (provavelmente do Seiscentos), Peruíbe (o único localizado no litoral), Queluz (mais recente) (Dick, 1997, p. 129). Destes, sete são identificados por topônimos tupis, uma forma prática adotada pelos inacianos para difundir a língua da terra e auxiliar na catequese. Os nomes indígenas dos aldeamentos do núcleo de São Paulo se mantiveram até hoje, incorporando-se aos municípios criados (Embu, Itapecerica, Barueri, Carapicuíba, Guarulhos), além de Peruíbe, fora da vila. Como as ordens religiosas eram responsáveis pela administração espiritual e civil desses núcleos, houve, depois da saída dos jesuítas de São Paulo, uma redistribuição gerencial dentre elas: com os padres capuchinhos ficaram São Miguel, Peruíbe e Escada; com os beneditinos, Pinheiros; com os carmelitas, Barueri (1698); Peruíbe e Escada (1735), com os franciscanos (1692) (Petrone, 1995).

Depois da atuação do Morgado de Mateus (século XVIII), em São Paulo, os aldeamentos, que significaram um passo importante para implementar o povoamento na vila e assegurar condições para aí manter os índios missionados, preservando-lhes a saúde e a sobrevivência, entraram, rapidamente, em decadência, mesmo aqueles mais próximos do núcleo central, do Colégio Jesuítico. Ficaram, porém, os 
seus nomes da primeira fase de sua constituição tornados municípios, como se disse, exceto Pinheiros, hoje bairro paulistano, e o aldeamento de Nossa Senhora da Escada, desaparecido.

Muito embora o idioma originário, responsável pela formação dos topônimos dos aldeamentos, tenha se extinguido, a permanência desses nomes como signos de segunda potência, não como forma de expressão e comunicação oral, mas apenas como identificadores de lugares, conserva, ainda, elementos morfofonêmicos que permitem uma recuperação aproximada do antigo estado da língua. Aliás, essa foi uma das conceituações primárias da toponímia, ou seja, um procedimento metodológico de investigação sintática, semântica, fonomorfológica,por exemplo. Convém transcrever aqui uma condensação de Machado de Oliveira (1867) sobre o significado dessas fundações etno-religiosas: “Tiveram a primazia em sua fundação Pinheiros, São Miguel e Barueri, pelas circunstâncias de acharemse suas localidades dentro do círculo que foi teatro das primeiras lutas travadas entre os conquistadores e as tribos dos Guayanazes que habitavam os Campos de Piratininga" (apud Dick, 1997, p. 121).

Os guayanás/guaianás, como dissemos, teriam sido os índios de São Paulo ou os guaianás do campo que Gabriel identificou como grupo étnico, e não como grupo lingüístico da mesma família dos tupis ou mesmo do grupo majoritário dos tupinambás, assim considerados pela maior distribuição costeira. Carvalho (1990, p. 462), em seu estudo sobre esses índios, diz que seriam prováveis ancestrais dos kaingangs, do que se pode deduzir sua origem dita tapuia no Quinhentos, por não procederem de famílias tupi-guaranis. Anchieta (1980), na Arte de Gramática,fez uma distinção lingüística quanto à realização dos temas verbais, mostrando que “o uso" seria o identificador mais seguro dos grupos aparentados: dos "Potiguares aos Tamoyos do Rio de Janeiro”, o traço fonético seria um, ao passo que "os Tupis de São Vicente, que são além dos Tamoios do Rio de Janeiro", apresentariam outras ca- racterísticas sonoras no âmbito da mesma família lingüística. Além desses índios, habitariam a Capitania de São Paulo os chamados puris ("gente miúda", donde põ$r u$, "comedor de carne humana"), incluídos entre os grupos de fala não-tupi, juntamente aos coroado-kaingangs (noroeste do Estado) e coroado-coropós .

De qualquer modo, as informações relativas a esses grupos são mais etnológicas que lingüísticas. Mesmo porque a toponímia não registrou (pelo menos nas fontes pesquisadas disponíveis) nem incorporou, na época colonial, topônimos dessas procedências, exceção feita aos kaingangs, atuantes a noroeste do estado. Os puris, pela localização mais afastada da vila (vale do Paraíba), não tiveram mesmo maior influência no cotidiano da população. Muito embora Dom Luis Antonio de Sousa, capitão general de São Paulo, tivesse pretendido formar um aldeamento com os puris "que se achão conquistados" para civilizá-los (e doutriná-los na fé cristã), a iniciativa não prosperou, pela resistência encontrada. Interessa-nos, porém, a descrição dos contatos realizados, para qual entrada levaram “Línguas e a Índia velha, fazendo-lhe todos os mimos” (Reis, 1979, p. 97). A intenção era torná-los “administrados”, segundo a terminologia da época, o que não conseguiram, não sendo possível, assim, formar "uma ou duas aldeias [...] com seu Superior ou Parocho e seu Diretor". Desde que necessitavam levar um língua na expedição, como intérprete, isso significava, realmente, quão pouco era conhecido o idioma.

Coroados e puris viviam do Rio Paraíba (SP) ao Espírito Santo, além da parte ocidental de Minas Gerais (Reis, 1979, p. 63), tendo sido considerados descendentes dos goitacás. Penetraram em São Paulo pelo próprio Vale do Paraíba, em terras do antigo aldeamento de Queluz. Sua língua, porém, era "diferente da de outras tribos", guardando alguma afinidade com a dos coroados e coropós (Reis, 1979, p. 73). O vocabulário das palavras puris, recolhido por Martius em 1863 (apud Reis, 1979), não permite aproximá-lo da língua falada em São Paulo, na época. Exemplos: 


\begin{tabular}{|c|c|}
\hline $\begin{array}{c}\text { VOCÁBULOS PURIS } \\
\text { EQUIVALÊNCIA EM PORTUGUÊS }\end{array}$ & EQUIVALENTES EM TUPI \\
\hline curari, choça & oka/maloca \\
\hline poté, fogo & tatá \\
\hline rangon, "gente branca" & caraíba, "o sagrado" \\
\hline joaré, "cão doméstico" & Jaguará \\
\hline
\end{tabular}

Falta, inclusive, melhor detalhamento sobre as partículas puris constitutivas ou elementos morfemáticos das palavras nocionais, que evidenciariam melhor a sua lógica interna ou formação morfossintática. Entretanto, o tex to é precioso e válido para uma amostragem.

Knivet (apud Reis, 1979, p. 95), no final do século XVI, encontrou esses índios entre a Serra de Itapeva e margens do Paraíba, nos atuais municípios de São José dos Campos, Caçapava e Taubaté, chegando até a barra do Rio Piraí. O mesmo aconteceu com os guaianás do campo, ainda que fossem mais conhecidos do que os puris, pelos relatos das Atas da Vila de São Paulo. Não se tem registros específicos de sua língua, mas, ainda que não integrando o estoque linguiístico do tupi colonial ou da língua brasílica do século XVIII, devem ter sido tupinizados, provavelmente, pelos falantes desse idioma. A toponímia paulista que foi se constituindo não tem traços de vocábulos de outras línguas que não o tupi colonial, mesmo dos kaingangs ou coroados.

Em Viotti (1962, p. 31), há informações etnológicas sobre os grupos mencionados: "Tanto Pinheiros ou Jurupatuba, como São Miguel ou Ururaí, eram lugares anteriormente conhecidos e habitados pelos índios tupi do Campo. Muito de propósito omitimos o apelativo de 'Guaianazes', equívoco em que incidiu e enredou até hoje muita gente e mesmo Frei Gaspar. [...]. A teoria de que os índios Guaianases eram tupis está hoje muito abalada, definindo-os como tapuias". Para o autor, os autênticos guaianás do século XVI seriam os maramomis/guarumimins ou guarulhos, $\mathrm{O}$ que não altera muito a problemática da língua (filiação genética) e da toponímia, que continuam sendo conhecidas e interpretadas pelo código tupi.

Outra referência à vinculação etnolingüística do grupo encontra-se em Almeida (1962), descrevendo os grupos históricos existentes no litoral sul do estado e a variedade terminológica com que eram tratados. Como já dissemos neste texto, do que não há discordância do pensamento do autor com o nosso, a família tupi era hegemônica nessa parte do território, repartindo-se, entre outros, em tupinambá e tupiñáki (ou tupiniquim); estes últimos atingiram a parte sul da costa, chegando na extinta Vila de São João Batista de Cananea: “Os cariboca, seus inimigos, que bem os conheciam, nomeavam também por tupi-ña-ki os Guaianá, sem embargo de alguns cronistas consideraram tapuias os mesmos goia-na. [...]" (Almeida, 1962, p. 208).

Entende-se, assim, por que essa região antiga do litoral de São Paulo, percorrida pelos índios costeiros costumeiramente até os Patos, era marcada por uma toponímia diferente daquela em língua portuguesa, o que acabou caracterizando a paisagem geográfica como um acento idiomático distintivo, fruto de uma outra semântica:

Pontal do Itacurusá ("cruz de pedra"); Ilha de Itacoatiara, depois Ilha do Cardoso ("pedra riscada"); Barra de Ararapira ("cabeceira das araras); Barra de Aririaia (var.de airi-aia, “as palmas do airi”); Rio Iguasú ("Rio Grande"); Rio Uruguai (prov. de uruguá-y, "rio dos búzios ou dos caracóis"); Vila de Itanhaen (prov. "vasilha de pedra"); Rio Iguape ("na baía”); Vila de Ubatuba 
(prov. ybá-tyba, "o frutal”; var. uyba-tyba, "flechal”, "abundância de flechas", "vegetal utilizado para a confecção de flechas", "canavial bravo"; var. ybá/ubá-tyba/ubátuba, "canoal"; alt. ybá>ubá - "canoa fabricada com casca de árvore” (Sampaio, 1987)); baía e porto de Paranaguá (“baía do rio grande", "baía fluvial”); aldeamento e Barra de Icapara ("rio ou canal torto", "braço curvo do rio" (Sampaio, 1987)); praia de Guaraquesaba (alt. baraqueçasaba, "lugar onde as aves guarás - garça-pousam”).

Dessa amostra de designativos, formados a partir de radicais e morfemas do tupi antigo, dicionarizados, posteriormente, como brasileirismos de um modo geral, muitas vezes sem preocupação de estabelecer os domínios de ocorrência, pode-se categorizá-los em campos semânticos específicos. Essa atribuição é significativa para a ciência onomástica, para estabelecer as inter-relações etnocontrastivas que deve objetivar. Pelo menos é esse o nosso entendimento, e foi também o que nos levou a propor o modelo taxionômico utilizado nos Projetos ATB (Atlas Toponímico do Brasil) e Atesp (Atlas Toponímico do Estado de São Paulo) (Dick, 1980 e 1996). Na exemplificação mencionada em Cananéia, há ocorrência de campos litotoponímicos, zootoponímicos, fitotoponímicos e geomorfotoponímicos, respectivamente, designações de origem mineral, animal, vegetal e relativos às formações hidromorfológicas.

Quando a Vila do Campo foi criada, em 1560, da qual a concausa foi a instalação do colégio dos jesuítas, em 1554, na colina, como principal adensador dos poucos habitantes no seu entorno, já havia, como em outros pontos da costa e mesmo no mediterrâneo, uma nomenclatura oriunda dos dialetos falados pelas famílias indígenas existentes, tupis ou não-tupis. Os designativos citados na toponímia litorânea são exemplos dessa ocorrência, e não podem ser postos em dúvida, primeiro pela antiguiidade dos registros cartográficos ou escritos, depois, pela natureza semântica dos significados, em uma projeção léxico-espacial comprovada e, ainda, pela manuten- ção das formas significantes além do período histórico marcado, gerando produtos analisáveis.

As expedições de reconhecimento da terra, a partir de 1501 (Dick, 1990, pp.81104), ao nomear os acidentes costeiros, deixaram a primeira marca vocabular contrária ao código existente e que exemplificamos com os nomes de rios e aldeamentos indígenas, bem como com as primeiras formas de uma língua transplantada (nomes portugueses). Num processo inverso ao comum ou ao que se espera em situações de contato, o modelo de fora se tornou o padrão local, a língua standard, por assim dizer; o idioma da terra, o nativo, acabou por se definir como o exótico, fora das bases estéticas conhecidas. Por isso, a toponímia, desde 1500 e nos anos seguintes, foi européia ou de matrizes europeizantes, os primeiros nomes se formando à maneira lusitana, impregnados de seus próprios valores. À camada autóctone se sobrepôs o vocábulo português, revelador de uma semântica muito mais religiosa e devocional do que física, de cunho descritivo-objetivo, a ressaltar os aspectos sensíveis do terreno, muito menos as qualidades não materiais ou subjetivas. Assim, São Paulo conheceu uma nomenclatura expressa deste modo: "caminho direto que vai do Anhangavahy a Santo Antonio, ou caminho direto do Pateo do Senhor Jesus à borda do sertão", traduzido no enunciado reduzido de Rua Direita; Rua do Cotovelo, também chamada de Rua da Quitanda; os Quatro Cantos (atual Praça do Patriarca); caminho do Paredão, atual Rua Cel. Xavier de Toledo; Rua da Forca; Rua do Pelourinho; Rua da Caixa d'Água. Note-se que os topônimos estão a exercer aí uma função dêitica, pragmática, e indicativa das circunstâncias da própria nomeação. Os santos portugueses de devoção popular ou padroeiros das próprias ordens religiosas tornaram-se também referência espacial obrigatória, atrelados no princípio necessariamente à igreja edificada, depois sem esse vínculo; caminho/rua do Mosteiro de São Bento (séc. XVI, depois Rua de São Bento, Rua São Bento); Rua, Várzea, Ater- 
ro de Nossa Senhora do Carmo (séc. XVII); Terreiro de São Francisco ( século XVIII); Rua de Santo Antonio (séc. XVII); Largo de Nossa Senhora da Misericórdia (século XVI); Páteo do Colégio do Senhor Jesus (século XVI); Rua de Nossa Senhora da Boa Morte (século XVIII); Matriz e Largo da Sé (século XVI); Largo de São Gonçalo Garcia (século XVIII); Rua de Nossa Senhora dos Remédios (século XVIII); Rua de Santa Tereza (século XVIII); por exemplo.

Os nomes indígenas quinhentistas continuariam, paralelamente a esses designativos, provando o imaginário português como transmissores de uma estranha enfabulação enraizada na própria terra; na quase totalidade, eram, como vimos, de natureza descritiva e indicavam realidades vivenciadas cotidianamente, em presença e não apenas de modo abstrato: tietê, o rio da terra ("água" ou "rio verdadeiro, próprio"); tamandua'tei ("rio do tamanduá verdadeiro"), tatuapé ("rio do caminho do tatu"); pacaembu (de paka-yembó, paca-córrego); saracura (espécie de galináceo) grande e pequeno; akuti (ribeirão da cotia); carapicuíba (rio do peixe acará comprido, o ruim; var. rio do cará (vegetal) comprido ruim). Todos esses nomes, retirados da linguagem cotidiana, revelando a presença do animal no espaço próprio da vila, indicativo,também, da familiaridade do homem com a espécie, vieram a caracterizar o campo semântico que denominamos de zootoponímia da cidade (Dick, 1990,pp. 255-84).Outros nomes, inseridos em outros domínios de experiência, empregados num momento preciso de observação direta, representam o grande laboratório vivo que a terra significava para o europeu em termos de aprendizado do meio: tijuco ("barro escuro"); tabatingüera ("barreiro de cor amarelada"); ybyrá,mirálpuera, pueira, poera (variantes) ("madeiras"), birapoera/virapoera/ ibirapuera; caaguasú ("mato grande”), caminhos de ybytantan (var. butantã, "terra dura"); de emboaçava/boaçava ("passagem, travessia”), todos eles conhecidos já no século XVI, inícios do século XVII.

O século XIX, principalmente, viu florescer, na chamada Imperial Cidade de São
Paulo, desde 1712, um outro elenco de indigenismos, até então pouco difundidos relativamente às formações quinhentistas tradicionais. A partir do Oitocentos, tornaram-se um referencial diferenciado, nesse ponto de vista, para os bairros fronteiriços à Mooca e Tatuapé, principalmente. $\mathrm{Na}$ "Planta Geral da Capitania de São Paulo, sob a direção do Dr. Gomes Cardim, Intendente de Obras - 1897", verifica-se que a Várzea do Carmo e o Aterro do Gasômetro traçavam uma linha descontínua de separação com o bairro do Brás. Com a Mooca, acontece praticamente o mesmo, pela construção da nova Estrada de Ferro Central do Brasil, que as Atas da Câmara separavam do Belém. A Estrada de Ferro motivou, por um lado, o aparecimento de paradas dos trens, até hoje conhecidas na região como os bairros da Quarta e Quinta Parada.Significam a toponimização popular do próprio fato social, como ocorre em outras circunstâncias motivadoras, já apresentadas neste texto.

As ruas novas abertas nesses núcleos trazem como motivos a configuração do terreno acidentado, mas a marca lingüística do termo específico é predominantemente tupi: Serra de Araraquara, Serra de Ariraia, Serra de Bocaina, Serra de Botucatu, Serra de Bragança, Serra de Itaquery, Serra de Itatins, Serra de Jaraguá, Serra de Apiahy, de Sabugaia, de Botucatu, de Juquery, de Paraibuna, de Tapety, do Japy, ao lado de alguns compostos portugueses: Serra de Morretes, do Monte Serrate, do Prelado. Quanto à grafia dos topônimos em estrutura simples, procurou-se transcrevê-los como constam da fonte primária (Carta de Cardim): ruas Acarahy ("rio do acará"), Aguapey ("rio do aguapé"), Parahyba ("rio ruim"), Boissucanga ("esqueleto de cobra"), Jabaquara ("toca do índio fugitivo"), Alambary ("rio do peixinho arambery"), Araçatuba ("araçazal”).

Entre os bairros do Ipiranga, Vila Prudente, Vila Ema, com divisa pelo Rio da Mooca, outros topônimos foram surgindo, com o mesmo vínculo linguiístico: Itupeva ("salto raso"), Itapetinga ("laje branca"), Ararytaguá (“barreiro das araras”), Ibituna 
("serra negra"), Itapitanguy ("rio da pedra vermelha"), Caçapava ("travessia na mata"), Sapucahy ("rio da sapucaia"), Paranapanema ("rio ruim, pouco peixe"), Caraguatatuba ("sítio dos caraguatá"), Iporanga ("rio bonito"), Itanhaén ("vasilha de pedra") (Dick, 1997, pp. 340-7).

Esses topônimos, apenas eles, para nós, já justificariam a complementação do trabalho por meio de um glossário das ruas levantadas, o que permitiria apreciar melhor toda a estrutura vocabular e sintática de cada unidade terminológica e a ser apresentado numa próxima etapa de pesquisa. O significado maior dessa intensa atividade de repensar e recortar o espaço urbano, à maneira como o autóctone demarcava o seu ambiente físico, trouxe como conseqüência a incorporação ao léxico do português do Brasil (PB) de inúmeros outros vocábulos. A entrada dessas unidades terminológicas pelo dicionário de língua, consideradas apenas como paradigmas léxico-lingüísticos, seria mais lenta e demorada. A toponímia acelera essa atividade pelo uso imediato do referencial sempre que dele se necessite, seja para uma localização imediata do objeto referido, seja para consolidar princípios teóricos ou práticos que o estudo das formas lexicais permite depreender, metodologicamente.

\section{AS LÍNGUAS DA TERRA}

Por tudo o que se apreciou até o momento, e o que daí pode ser intuído, conclui-se que o Brasil nunca foi um país monolíngüe, apesar de, tradicionalmente, ser assim considerado. Levando-se em conta apenas a situação oficial, da ascensão de um único código como língua vernácula, a partir da padronização dialetal da comunidade de falantes, então se poderia admitir o acerto da decisão tomada. Ela também se prende à delicada situação de terras colonizadas, em que a língua materna da metrópole se torna também a língua das colônias e,portanto, uma língua transplantada, “apesar das diferenças de prosódia" que não afetaram a unidade e a compreensão do idioma em todas as regiões. Para Elia (1998, p. 29), no português, entre os traços sociolingüísticos que apresenta, estão o que chama de língua nacional, "praticada" por todos, e o de língua materna, "aprendida desde o berço", primeira língua praticada pelo falante, apesar dos chamados "bolsões" de línguas indígenas, como denomina o contingente nativo. A designação de língua vernácula atribuída ao português do Brasil foi conseqüência do fato de ser a "mais representativa do falar de uma região [...] a feição mais pura do falar materno" (Elia, 1998, p. 71).

Comparando-se o que Anchieta coloca na Informação do Brasil (1584) sobre as sete capitanias nomeadas da Província (Pernambuco, Bahia, Ilhéus, Porto Seguro, Espírito Santo, Rio de Janeiro, São Vicente), além de uma outra de Pernambuco, a que chamam de Tamaracá (Itamaracá, "pedra que canta", "sino"), e as observações sobre a população nativa da costa e aquela espalhada pelos sertões e pelos matos, chamadas, na época, de tapuias, "que não fala o idioma da costa", configura-se aí o primeiro esboço de uma tipologia de línguas indígenas do Brasil (LIB): "Destes tapuias foi (a terra) antigamente povoada como os índios afirmam e assim o mostram muitos nomes de muitos lugares que ficaram de suas línguas, que ainda agora se usam, mas foram se recolhendo pelos matos e muitos deles moram entre os índios da costa e do sertão" (Anchieta, 1964, p. 11).

Comparando-se, novamente, as informações de Anchieta com as do padre Fernão Cardim (1980,pp. 101-6), visitador das missões brasileiras, em 1580 , verifica-se que este, pela mesma época de Gabriel Soares e do inaciano, arrolou setenta e seis nações tapuias que reconheceu serem "gente das mais diferentes línguas", "gente brava, silvestre e indômita", inimiga dos demais povos costeiros. "Da costa e do sertão até o Paraguai” estão as que os portugueses entendiam por serem uma só língua "fácil, elegante, suave, copiosa”. A dificuldade principal, dizia Cardim, “era ter muitas 
composições" (por exemplo, Itaquaquicetyba = "taquaral cortante como faca"; Pindá-monhang-haba = "lugar onde se faz anzol").

Não há dúvida, portanto, de que o Brasil não teve uma só língua indígena, ou o tupi, como se pensava na época. Os povos que lhe eram contrários, distribuídos em diferentes grupos étnicos ou nações, hoje termo preferencial, falam diferentes línguas. Modernamente classificadas como integrantes do tronco makro-jê, mantiveram, aproximadamente, no país, as mesmas áreas para onde se deslocaram desde o Quinhentos. As regiões ambientais menos agressivas, mesmo no interior, próximas aos rios piscosos e aos vales férteis, bons para a agricultura, eram os domínios dos tupis. O que era muito extenso em termos de território.

As informações de Anchieta (1964, p. 45), relativas ao predomínio das dez nações de falantes da língua brasílica, situam essa área do Rio Maranhão até a terra dos carijós, estimando-a em "800 léguas da costa, em todo o sertão dela que se estenderá com 200 ou 300 léguas". O uso era comum, com ligeiras variações tópicas, entre essas nações, depois estendida a prática aos europeus transmigrados, por ação dos mamelucos. Durante dois séculos, a fala de São Paulo teve essa característica. A partir do século XVIII, porém, a língua tupi foi deixando de ser falada pelo avanço do português como língua-base da população, e pelo desmantelamento da situação colonial anterior (maior uso da língua tupi pela população mameluca), por decisão da Coroa, as linguagens ditas "bárbaras, rudes, selvagens" conseguiram sobreviver, em uma boa percentagem. Formam um contingente significativo de línguas vivas no país; funcionam, na realidade, como estruturas lingüísticas autônomas entre si com traços morfológicos, fonéticos e sintáticos que evidenciam uma outra origem genética. Mas ainda não chegaram a constituir-se em uma língua geral, como ocorreu com a língua brasílica dos séculos XVII-XVIII, marcando o panorama das linguagens brasileiras. Fala-se na tendência à "tucani- zação" dos idiomas do Alto Rio Negro, dimensionados pelo tukano. É certo também que, na própria Amazônia, nos seringais, entre os caboclos ribeirinhos, mestiços e cafuzos, ainda se empregam termos da chamada "língua geral do Amazonas", no século XIX, resultante da evolução estrutural do tupinambá-tupi antigo, por influência dos contatos externos com outros povos não-índios, em especial, o português A área de circulação vocabular e da freqüência lexical é restrita, não atingindo o restante do país, que interage com os termos do tupi antigo, em desuso desde o século XVIII, como língua de circulação. A toponímia brasileira é o centro de sua memorialística, estudando as variações lexicais, fonéticas e morfológicas registradas nos designativos. O mapa lingüístico indígena do Brasil mostra essa concentração natural das línguas, e a cartografia toponímica que vimos realizando, sincronicamente, nos dois projetos que coordenamos (Atlas Toponímico do Brasil e Atlas Toponímico do Estado de São Paulo), indica as áreas indígenas residuais, resultantes das derivas de línguas: “Aqueles portugueses que viviam em áreas em que predominavam os ameríndios possivelmente falavam algum tipo de dialeto de contato como a língua geral, além dos seus dialetos portugueses" (Mello,2002,p.350). No caso dos dialetos portugueses vindos com a população falante, pode-se anotar, para reflexão futura, o falar açoriano-catarinense, com as modificações decorrentes da transplantação, na segunda metade do século XVIII, em que o estudo de Furlan (1989) coloca em questão as modificações da própria língua transplantada no Brasil. Destaca também o que chama de "assíduo intercâmbio com o falar paulista (dos moradores de São Vicente)", já intuindo as alterações ocasionadas pelo meio ou impulsionadas pela própria deriva.

Edelweiss, ao estudar as várias obras publicadas sobre a dialetologia indígena brasileira, a partir da gramática de Anchieta até o nheengatu do século XIX, conceitua o que entende por língua brasílica ou língua tupi e por língua geral. No primeiro 
caso, diz ser "o acervo de formas lexicais, preceitos gramaticais e textos que os jesuítas deixaram compilados em seus compêndios e produções até o fím do século dezoito". Seria a "maneira de falar" dos grupos costeiros, generalizada pela procedência comum do mesmo tronco genético, fixada ou documentada pelos inacianos, o que se chama de tupi antigo (Edelweiss, 1969, p. 73). Ainda diz que por "língua brasílica ou tupi compreende-se tão só o dialeto unificado dos compêndios jesuítas, geralmente sem especificações das divergências locais" (Edelweiss, 1969, p. 99). Definido (o tupi) como a "língua mais usada na costa do Brasil”, por Anchieta, em sua Arte (1595), tornou-se por isso, pelo uso "das diversas partes do Brasil", a "língua geral” da costa, ou "tupi modificado por efeitos de aculturações e de mestiçagens [...]. Nada inventaram e nada modificaram na respectiva lexicologia" (Edelweiss, 1969, p. 50). Completa, ainda, esse entendimento, mostrando a sua lenta evolução de uma fase anterior da língua ao estágio médio de seu desenvolvimento, antes de sua fixação modificada no que se chama de tupi moderno. Resultante da aproximação entre dois grupos étnicos diferentes, e de falas distintas, foi muito difundida pelos mestiços de primeira geração, os descendentes mamelucos desse cruzamento luso-ameríndio. As diferenças lingüísticas entre esses dois momentos de um mesmo sistema estrutural estão consignadas, respectivamente, no Vocabulário na Língua Brasílica (Drummond, 1952-53) e no Códice no 69, da Biblioteca da Universidade de Coimbra, contendo a "Gramática da Língua Geral do Brasil, com hum Diccionario dos vocábulos mais uzuais para a intelligencia da dita Língua (século XVIII - 1750)".

Nesse mesmo período de contatos de populações alógenas e autóctones, releva também que os africanos aqui aportados, desde o século XVI, também tiveram duas línguas gerais brasileiras representadas pelo grupo quimbundo (hoje línguas kwas), do Nordeste, com pontos de difusão principal em Pernambuco e Alagoas, e o yorubá ou nagô, da Bahia. Cada uma delas modifi- cando, sem dúvida, não só o próprio stock vocabular como influenciando os seus interlocutores.

Esses elementos diferenciadores das primitivas camadas de cada um dos grupos isoladamente considerados, ao interagir entre si, acarretam os cruzamentos vocabulares, por força dos chamados adstratos lingüísticos. Colocam-se, assim, as situações de bilingüismo, diglossias, pidgnização ou crioulização, com maior ou menor intensidade, seja do ponto de vista da própria língua ou histórico-social. Visto o problema, aqui, do ângulo das línguas nativas, pode-se perceber por que não é estranho dizer que o aprendizado das línguas da costa foi, de início, mais histórico que gramatical. "Falar a língua" era uma contingência instrumental para o europeu; representava um eixo axiológico de valores, pressupondo a posse e domínio da terra, a relação dominante/dominado, com suas conseqüências culturais, a fixação do poder eclesiástico e do poder temporal monárquico.

Em relação ao cruzamento das línguas, há de se considerar, ainda, a questão do prestígio do novo código ou da "língua de civilização" em relação àquela da terra, tornada, com o passar do tempo, uma fala minoritária. Outro fator a se considerar, nessa situação nova de enfrentamentos desconhecidos, era a própria mística do imaginário a envolver a chegada dos europeus. Considerados os caraíbas ou heróis sagrados, vieram do oceano para conduzir o grupo à "terra sem mal", "onde nunca se morre", a chamada de yby-marã-e $\tilde{y}$. Por isso os tamoios e tupinambás de Angra dos Reis Magos, no Rio, nomearam os franceses de mayr, o "ungido", "há tanto esperado". Nas sociedades contemporâneas, porém, o movimento lingüístico é reverso, os que perderam a língua nativa querem recuperála, por um princípio de identidade, o que lhes garantirá a cidadania plena, como membros de duas comunidades de hábitos culturais próprios. Essa noção de língua como fator identitário grupal está hoje muito ligada à posse e permanência no território dos ancestrais, que é a sua própria referencialidade. O "ser índio", atualmente, 
retoma essa simbologia, fruto de uma canalização de esforços coletivos.

A convivência múltipla de mais de 200 línguas faladas no território gerou, como conseqüência do plurilingüismo étnico e cultural, um bilingüismo de caráter mais individual, não estatal e coletivo. Logo, a Coroa portuguesa, em 1758, pelo diretório de Pombal, procurou apagar a intromissão da fala tupi no código lusitano. O desaparecimento da língua atingiu, também, num primeiro momento, os nomes de lugares de origem indígena, que eram a parte visível do processo lingüístico, como seu produto facilmente identificável; foram substituídos por locativos portugueses, exportados da matriz para a colônia, caracterizando, dois séculos depois, o segundo momento da transplantação denominativa lusitana para o Brasil, ou decalques semânticos.

A aquisição da competência lingüística em ambos os códigos, tupi e/ou línguas indígenas, teve conseqüências formais. Teodoro Sampaio (1987) usa a expressão “falantes do tupi”, o que sugere o uso doméstico, coloquial e familiar da língua brasílica nos atos quotidianos do indivíduo e da comunidade. O português seria empregado nas conversações e atos formais, sendo detentor do código escrito, contrariamente às línguas ágrafas da terra.

As referências históricas a esse fato são de variadas origens e se fazem presentes em várias fontes. Wandruzka, referido por Montes Giraldo (1982, p. 23) diz que "ce que nous avons coutume d'appeler 'une langue' [...] n'est pas un monosysteme un et uniqué; chacune est, en realité, tout un conglomérat de langues, un polysistème composé de constantes et de variantes entrelacèes, imbriquèes les unes dans les autres. Les dialectes, les patois, les pailers régionaux et locaux, les langages specifiques des différents groupes sociaux, des différentes situations socioculturelles, ne se définissent comme tels que par rapport à un denominateur commun, à une langue commune théorique [...]" (2).

O que havia na colônia, portanto, não diferia de outras formas de colonização em que etnias diferenciadas se colocaram em contato, gerando um bilingüismo pelo menos individual e assimétrico; ou seja, monolingüismo na língua de partida (ou tupi ou português, aquela que entrará em confronto com os outros códigos), bilingüismo em seguida, traduzido pelo aporte de uma segunda língua e, depois, muitas vezes, o monolingüismo, pela incorporação de um dialeto ou sistema em outro, com as interferências decorrentes, que podem persistir ou não. A convergência sociocultural da população indígena brasileira para a sociedade portuguesa, como resultado da assimilação do que restou do grupo tupi costeiro, depois da fase da língua geral, ilhando-se no nheengatu amazônico, e esvaziando o restante do país em relação a esse falar, acabou por eliminar a questão bilíngüe mencionada. Os remanescentes nativos nivelaram-se, no Oitocentos, no mesmo plano dos falantes naturais do português, que tinham o idioma como língua materna ou que nunca foram bilíngües totais, apenas conhecedores de um vocabulário de origem brasílica, que podiam usar, ou não, na comunicação. Criou-se, como conseqüência, no idioma transplantado, dois níveis sistemáticos, o que veio a se chamar língua culta, segundo os padrões normativos da gramática, em sua codificação e a fala popular (ou português popular), aberta à aquisição vocabular, e aos torneios estilísticos, mas principalmente sintáticos. Ainda que do ponto de vista teórico, a respeito do assunto, tanto Garvin (Atas, 1979, p. 127), quanto Lope-Blanch (Atas, 1979, p. 105), na mesma ocasião, tenham afirmações um pouco distintas, o que releva é o posicionamento trazido como subsídio aos estudos da interferência lingüística: para Garvin, as diversidades de uma língua, em suas manifestações, ocorrem em função das alterações do próprio sistema, em estágios diferentes de resolução, para Lope-Blanch, os fatores históricos, internos ao processo da língua, no caso o português e o espanhol, devem ser completados pelo reconhecimento dos fatores externos de modificação, que são as línguas de substrato e línguas de adstrato, indígenas e africanas, e as de superestratos
2 "O que nós costumamos chamar 'uma língua' não é um monossistema um e único; cada um é, na realidade, um conglomerado de línguas, un polissistema composto de con tantes e de variantes entreloçadas, imbricadas umas nas outras; os dialetos, os patois, os falares regionais e locais, as linguagens específicas de diferentes grupos sociais, de diferentes situacões socioculturais, não se definem como tais senão em relação a um denominador comum, a uma língud comum teórica, à qual se |gam por uma maioria de cons tantes e da qual se afastam em por) uma minoria lque é talvez uma minoria bastante forte) de variantes" (tradução minha). 
culturais, ou européias propriamente ditas (inglês, francês e italiano).

Sala (1988,p. 17), baseando-se em Uriel Weinreich (1953), discute as duas modalidades de contatos ou interferências de línguas que se apresentam, o modo direto e o indireto, o primeiro, ocorrendo no mesmo território, pelos cruzamentos étnicos, em períodos consignados, o que aconteceu na América, e o indireto, característico da língua escrita, "pelas relações culturais, econômicas e políticas" dos grupos. De qualquer modo, são fatores extralingüísticos que permeiam esses dois blocos de realizações, com maior visibilidade para o primeiro (contato direto), pelos efeitos mais imediatos em ambos os códigos: dominância de um sobre o outro, transparência de elementos vocabulares ou culturais, até o desaparecimento ou extinção daquele de menor prestígio ou de menor potencial socioeconômico: "A nivel de la colectividad, la prolongación de la fase del bilingüismo puede conducir al abandono de una de las dos lenguas: en el caso del sustrato se pierde el idioma de las poblaciones aborígenes; en el caso de superestrato, el bilingüismo acaba con la desaparición de la lengua más nueva" (Sala, 1988, p. 18).

A substituição das línguas, porém, traz o aporte das substituições, ou mudanças culturais, que podem levar ao desaparecimento da sociedade como um todo, assimilada pela outra, de maior prestígio, seja em termos de aculturação, assimilação ou deculturação. No caso das populações indígenas brasileiras, essa imersão no novo meio, de acordo com Galvão, ocorreu mais comumente no mundo caboclo; a adoção desses valores, que substituíram os tradicionais, próprios e étnicos, é a resultante, para o autor, "do impacto de trezentos anos de convívio geralmente pacífico com nossa sociedade rural" (Galvão, 1957, p. 71).

É, assim, das alterações sociais e lingüísticas vivenciadas pelos grupos em presença, quer pela necessidade de novos usos ou conhecimentos introduzidos, espontaneamente ou não, mas que modificam a visão global de mundo já consolidada, quer por alteração até do próprio meio natural, recortado, agora, por uma outra linguagem, ou outros dizeres, que as "línguas gerais" acabam por encontrar espaço para sua instalação. O que não significou, no nosso caso, o estabelecimento de um outro padrão de estrutura sistematizada, distinto do de Portugal.

Aplicando-se, porém, os princípios antropológicos de Galvão e, principalmente, o modelo lingüístico desenvolvido por Sala à sociedade paulistana dos primeiros tempos, verifica-se que as interferências comportamentais ocorreram em ambos os tipos, nos contatos diretos e indiretos. No primeiro caso, pelo aprendizado necessário do outro código para viabilizar a movimentação no espaço, demarcado por expressões indígenas ainda desconhecidas. A apreensão do meio americano se fez pela oralidade, num predomínio do fonocentrismo. O contato indireto surgiu como imposição da própria ordem religiosa, fruto das missões catequéticas nos aldeamentos, de cunho evangelizador. Integram esse plano as versões dos catecismos românicos, ou das doutrinas cristãs simplificadas e das próprias orações fundamentais do cristianismo, o credo, o pai-nosso, a ave-maria, as ladainhas. O mérito dessas produções, independentemente de seu artificialismo semântico, encontra-se não apenas na transposição lingüística de um ideário, mas nos efeitos práticos decorrentes dessa atividade, como o aparecimento dos primeiros neologismos (ou lusismos) da terra, com utilização dos seus próprios significantes (da língua de chegada); a manutenção dos significantes da língua de partida (português) ocorreu nos casos em que os elementos definitórios eram inexistentes ou insuficientes para traduzir a idéia ou o conceito perseguido. Como exemplos, citam-se, na Doutrina e Perguntas dos Mistérios Principais de Nossa Santa Féna Língua Brasílica (Ms. I do Códice no 7; Chrestomathía, 1859), as unidades lexicais portuguesas mantidas na versão da Igreja:

Santa Cruz: Pelo sinal da Santa Cruz "Santa Cruz raangaba resé";

Ave Maria: Ave Maria cheia de graça - 
"Ave Maria, graça resé tynysémbae";

Credo: Creio em Deus Pai, todo poderoso, criador do céu e da terra - "Arobiar Tupã Tuba opakatu mbaé tetiruã/moñánga eikatúbae Ybáka (céu); yby (terra) abé moñangara (criador)".

Nos Mandamentos da Santa Madre Igreja (asé reKomoñangaba), não há sinonímia ou equivalência no tupi para "Santa Madre Igreja”, "Domingo”, "Páscoa”. Já a Santíssima Trindade teve seus conceitos referencializados na língua: Tupã Tuba (Deus Pai), Tupã Tayra (Deus Filho); em Deus Espírito Santo (Tupã Espírito Santo) o equivalente a Deus foi transposto do português.

$\mathrm{Na}$ "Oração para Dizer pela Manhã e à Noite", as unidades "Jesus Cristo" e "Amém Jesus" não foram vertidas, apenas "Nosso Senhor", Che Iarà, donde a expressão completa: Che Iara Jesus Cristo, na "Oração a Todos os Santos". O vocativo "Todos os Santos" foi revertido para Santos etá (morfema de plural), assim como o "Papa de Roma” ou Abaré Guassú ("padre grande"). No Diálogo da Doutrina Cristã pela Língua Brasílica, ficam com as formas portuguesas os significantes "penitência", "Purgatório", "Santíssimo Sacramento".

No Ms III, Códice no 9 do mesmo Diálogo, "Santa Maria" não traz equivalente semântico. Já para "Anjo da Guarda”, a língua possuía significantes possíveis, gerando-se o neologismo Karaíba-bebé ("o homem santo voador") / Karaibebé.

O volume I das Atas da Câmara da Vila de São Paulo contém a descrição das reuniões realizadas de 1562 a 1596 . Os assuntos tratados faziam parte do cotidiano da vila, retratando as necessidades imediatas dos habitantes de um pequeno burgo de 100 fogos e 1.500 moradores, no máximo. Esses textos, escritos segundo a sintaxe portuguesa da época, com as abreviaturas das formas lingüísticas usuais, trazendo na folha de rosto a indicação dos camaristas responsáveis pela vereança, Jorge Moreira, Luis Martins, João Rodrigues, Salvador Pires e Lopo Dias, não informam, porém, no discurso utilizado, nenhum dado pelo qual se pudesse deduzir qual o uso corrente da língua brasílica (ou tupi) como forma de comunicação lingüística. Não há expressões corriqueiras que sugerissem essa interferência de línguas ou a substituição do português pelo tupi, na fala, a não ser na toponímia. Mesmo porque o registro das Atas, apesar de simplificado, é bastante direto no sentido de determinar o que deve e o que pode ser feito pela população, como obrigação, aplicando-se multa em caso de desobediência. Uma dessas proibições era o impedimento de os homens úteis da vila descerem ao sertão, para o preamento dos índios: “[...] que fose apreguado q toda a $\mathrm{p}^{\text {a }}$ morador nesta villa cõ pena de sem rs [cem réis] pasante as outavas da festa lloguo ao dia seguinte mandacẽa fazer o caminho do $\mathrm{c}^{\mathrm{o}}$ [conselho] q vai daqui $\mathrm{pr}^{\mathrm{a}}$ virapoeira [Ibirapuera]" (Atas I, 30.03.1575); "que cada hũ deles cõ pena de seis mil rs e dous anos de degredo $\mathrm{p}^{\mathrm{a}}$ fortalleça da bertyogua" (Atas I, 22.06.1572).

A ata de 12 de maio de 1564 interessa a estas considerações porque registra o nome da vila sob a forma de São paulo de piratiñ̃ ao invés do usual Piratininga: "[...] lembramos ha vosa mercê - como esta vila de são paulo sẽdo a tãtos anos edifiquada doze léguas pela tera dentro e se fazer cõ muito trabalho longe do mar e das vilas de Sãotos e de São visente [...] e esta quapitania de são visẽte esta ẽtre duas geracoes de gente de varias quolidade e forsas $q$ ha ẽ toda ha costa do Brasil como são os tamoios e topinaquins dos topinaquins ha quinze anos a esta parte q sempre Matão no sertão omẽs brãoquos como matarão a [...] e não satisfeitos cõ isto não lhes fazendo a gẽte desta quapitania mall nhũ [mal nenhum] quemarão as pazes q conosco tinhãoe se ergerão e vierão sobre esta vila e a tiverão [...]; o outro genoro de gẽtio tamoio q posue ha banda do rio de janeiro tem dado muita hapresão as vilas de são visẽte e sãotos" (Atas I, 12.05.1564).

A significação dessa ata, sem dúvida, vai além do discurso formal dos camaristas, pois revela, na linguagem direta, a situação da vila frente aos índios inimigos, identificados como tamoios e tupiniquins, vindos do Rio de Janeiro e pondo em sobressalto 
a São Vicente, cabeça da capitania, e o seu porto, a Vila de Santos, depois que os índios romperam o acerto de paz que tinham com a Vila de São Paulo. Outras vezes, como na ata de 14 de setembro de 1583 , os camaristas identificam o grupo indígena próximo, empregando apenas o genérico gentio do sertão.

Passando-se a outra fonte escrita, mas que não foge ao estilo discursivo comentado nas Atas, as Cartas de Datas de Terra, 1833 a 1835 , nota-se que o objeto da discussão é mais restrito do que aquele apresentado nas Atas quinhentistas, em que o inimigo comum, o gentio do sertão, no século XIX, já não encontra o mesmo espaço que lhe fora dedicado em 1560 e seguintes. Ainda fica visível o salto que a vila deu, passando de uma pequena povoação, durante todo o século XVI, à Imperial Cidade de São Paulo, título consolidado já no Setecentos. Esta cidade que se urbaniza tinha, de fato, outras preocupações, como esta: "se passar Carta de Data com as dimensões seguintes [...], em cada lado confinando pela frente com a rua projectada, que deve atravessar aquelle cano, partindo das terras do Desembargador Manoel da Cunha de Azevedo Coutinho Souza Chichorro às do $[\ldots]$, de um lado com o terreno devoluto [...] nos fundos do que se concedeu ao Dr Clemente Falcão de Souza" (Atas XXVII, 24.12.1833); "fecho que pretende fazer em uma tapera no bairro do Guapira" (Atas XXVII,07.01.1834); “fechar um terreno que possue na paragem guaricanduva (Aricanduva) na freguezia do Braz" (Atas XXVII, 14.01.1834); “pedindo sobras de terreno no lugar denominado Porto Geral do rio Tamanduatehy" (Cartas XI).

O que se nota nas Cartas, entretanto, é uma preocupação maior com os pedidos de lotes em ruas, bairros, freguesias, recursos que mostram o desenvolvimento da cidade, alguns destes logradouros já tendo desaparecido na mudança dos séculos: "na estrada que vai para o Ó [Nossa Senhora do Ó] adiante do tanque do Arouche [desaparecido]" (Cartas XI,07.07.1834). Também desapareceram a Rua do Rego da Pólvora (Cartas XI, 14.07.1834), a Rua da Espe- rança (Cartas XI, 14.07.1834) "ruada Cruz, detrás da Chácara de Dona Gertrudes Galvão" (Cartas XI, 24.07.1834). Às vezes, há necessidade de atualizar a informação, retirando-lhe o caráter coloquial: "principiando a testada na encruzilhada da estrada velha, que vai para a Cantareira, seguindo a Estrada de Cachoeira até a cabeceira do Ribeirão chamado Agoa Fria [...] com as duas estradas do Barro Branco (Santana) Caixoeira" (Cartas XI, 27.07.1834).

A mudança de três séculos da primeira ata (1562) para essa coletânea de requerimentos e petições solicitando chãos no espaço urbano e não na roça mostra que os moradores já não saem da vila para isso (ir à roça) nem para guerrear com índios hostis, antes amigos.

Já em relação ao boletim do Departamento do Arquivo do Estado de São Paulo, Tempo Colonial (1721-1804), que registra requerimentos dos moradores de São Paulo, apresentando solicitações de interesse próprio, pode-se dizer que se situa numa etapa intermediária, entre as Atas mais antigas (1562) e as do século XIX. Traz, ainda, conteúdos relativos aos aldeados e, portanto, o discurso será mais dirigido, numa sintaxe ainda prolixa: "pedido de des Índios da Aldeias Reais pagos a sua custa, por que ouve omissão em se darem os Índios ao supplicante, $[\ldots]$. Entrou o supp ${ }^{\text {te }}$ $\mathrm{pl}^{\mathrm{o}}$ termo da $\mathrm{V}^{\mathrm{a}}$ de Sorocava e passando a corda de Ibiticatú para diante buscou o Ryo Grande para o passar na vizinhança do Rio Pardo, por ser esta a parte livre do risco do Gentio nação Cahyapó" (Atas I, 1562); “Diz a Veuva Sebastiana Leite Furquim q'de seo poder fugio hum Carijó de sua administração por nome Joaquim Sapateiro [...]" (Atas IX, 24.2.1723); “tem huma negra do gentio da terra de sua administração por nome Benta" (Atas IX, 24.2.1723); em 13 de abril de 1738 , consta a solicitação de entrega de “huma sua Carijó” (Atas IX, 24.2.1723).

Em outros requerimentos ainda continuam as referências sobre índios e índias carijós: requerimento de 4 de maio de 1723 - "Liberdade e inocência de hum pobre índio". Nesses anos iniciais do século 
XVIII, nos requerimentos dos suplicantes aos oficiais, o que se destaca é o emprego das expressões genéricas "índio desta aldeia", "índios que vivem fora das suas aldeias por cazas de alguns moradores", "destituída e com falta dos índios".

Ainda existia, em atividade, a Aldeia dos Índios de Nossa Senhora da Escada, na qual se fez um inventário da população indígena, administrada pelos carmelitas. A relação de moradores, apresentada por Antonio de Pontes, das índias da aldeia mostra que os antropônimos escolhidos são todos portugueses, não constando nenhum que indique a origem tupi ou qualquer outra procedência, a saber: Lionarda, Rosa, Joana, Maria Francisca, Anna Maria, Paula, Domingas... Essa forma de chamamento revela o grau de assimilação da cultura e hábitos portugueses em detrimento dos usos étnicos. De acordo com o relato de frei Constantino de Santa Maria, em 10 de março de 1722, a “Aldeia de São João, por essa época, já estava diminuta de gente $\mathrm{p}^{\mathrm{a}}$ poderem acudir aos servissos de El Rey meu $\mathrm{S}^{\mathrm{r}},[\ldots]$ que estas minas tem destruído as Aldeas, porque quem os leva os não trazem mais [...] e lá morrem, e as pobres mulheres aqui ficam ao dezemparo. Agora fica a Aldea sem ter quem me vá pescar hum peixe $p^{a}$ pasar com meu companhero; so me ficam sinco velhos [...]".

Os aldeamentos citados, ainda que estivessem no centro ou no entorno próximo à Vila do Campo, faziam parte, como foi dito, do Círculo de São Paulo. A pobreza desses núcleos e a falta humana, porém, não possibilitavam o aproveitamento dessa mãode-obra em benefício dos portugueses, como o religioso salientou relativamente a sua penúria. Essa situação, provavelmente, só tendeu a se agravar, com o pedido rotineiro de envio dessas peças ao governador de Santos, que deixava a aldeia, como se viu, ao desamparo quase completo pela ausência-inexistência de homens válidos para a execução do trabalho diário: "Manoel Peres bastardo q' fora casado na Aldeya com hua índia por nome Maria Gonsalves este não obedece a Aldeia e nem quer vir a missa [...] e não obedecem" (Atas IX,
22.01.1723). A remota presença da língua materna na memória dos descendentes parece continuar em certas falas do sacerdote, principalmente quando se refere ao sexo das crianças. A indistinção do gentio masculino ou feminino na língua brasílica fez que os termos homem/mulher ou menino/ menina não fossem usados como fatores distintivos. À maneira do tupi, usavam, ainda, expressões singulares, de pouca aplicação no discurso geral, que exigiam, pela repetição nos textos, a referência a macho e fêmea. Assim: "Maria das Neves tem três filhos duas fêmeas e hum maxinho e há ainda de peito que poderá ter hum ano". Essas expressões, porém, eram aplicadas aos animais, muito comumente, traduzindo, uma, o apyá (macho, em geral), e a outra a fêmea (cunhã), pelo que se nota que a indicação do sexo humano/não-humano não era marca específica no código empregado.

Quanto às etnias em contato, cita-se a seguinte informação: "Entre os índios q' servindo aos brancos como cativos, ao modo da terra, $[\ldots]$ ficarão $m^{\text {tos }}$ mulatos, $f$ de negras d'Angola q' por terem servido bem a seos senhores ficarão forros" (Atas IX, 12.03.1722). Essa transcrição é exemplar, pois dá conta: a) do tratamento escravo dispensado aos índios, como era uso na terra; b) da existência de mulatos, resultantes da união de mães negras, legítimas africanas de Angola, escravizadas em África e trazidas ao Brasil, mostrando que nem sempre a expressão negros/negras da terra é conotativa (aplicada aos índios escravizados), mas denotativa, vinculada, diretamente, aos grupos africanos; c) e, ainda, de que a expressão índios, ou índios da terra ou índios da Aldeia e as demais variações temáticas ("índios velhos", "hua índia com hua cria") indicam uma perda étnica, o abandono de uma identidade que nunca lograram exercer, mesmo que o grupo filial viesse acrescentado a um prenome português (Anna Paiaguá); d) em 14 de dezembro de 1800 , consta uma relação feita pelo padre Francisco das Chagas Lima, primeiro pároco de aldeia de São João de Queluz, de índios conquistados dos matos e que 


\section{Projeto ATeSP - Atlas Toponímico do Estado de São Paulo (Versão 2004)}

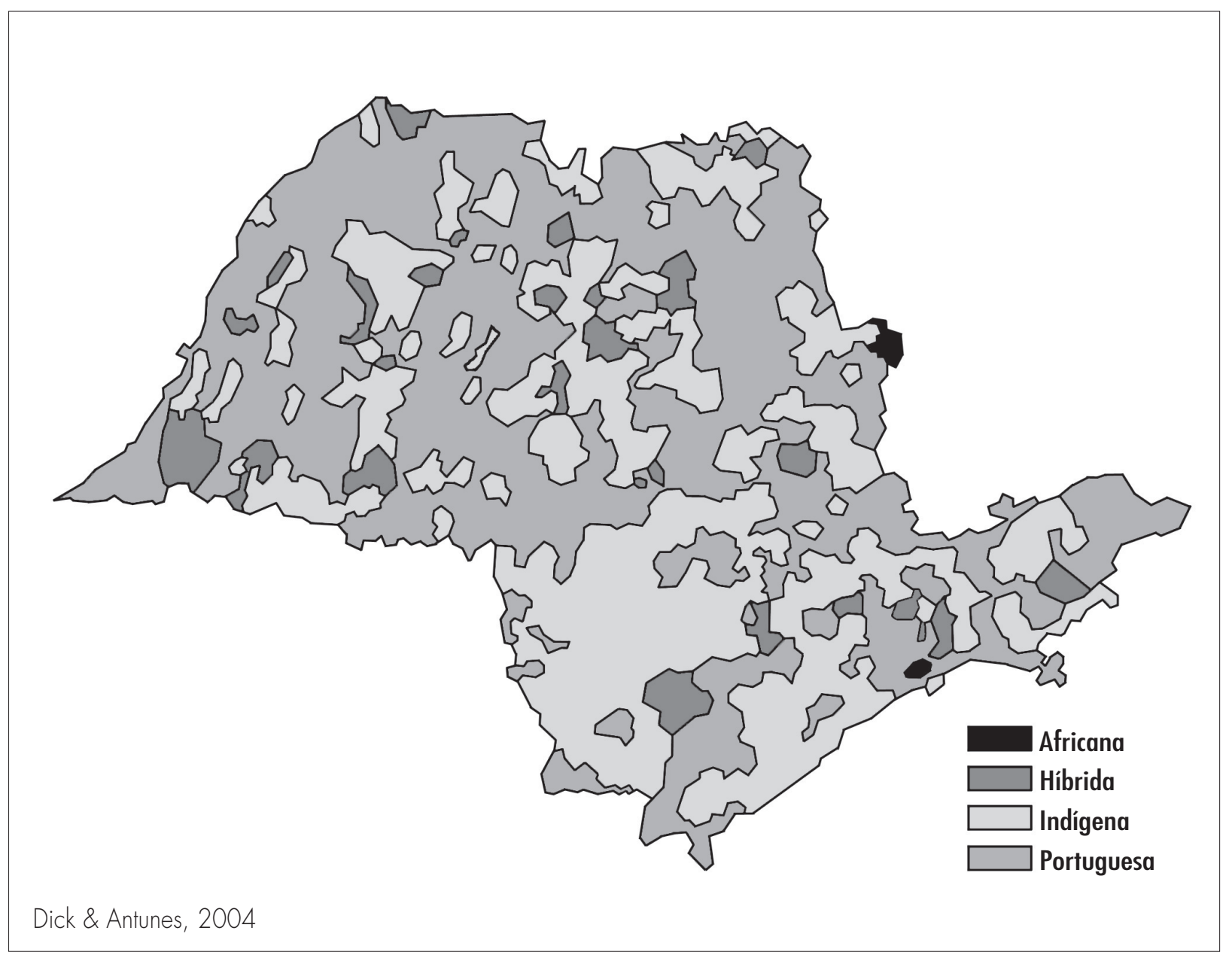

trazem nomes bárbaros de nascimento paralelamente aos novos nomes impostos: Chanin, Axiqué, Putú, Xicá, Ágüe, por exemplo. O encaminhamento foi dirigido a D. Antonio de Mello Castro e Mendonça, e consta de 86 nomes em língua que não a tupi, ao que parece, pela qual foram batizados com os nomes de sua provável filiação étnica, como disse o Padre Francisco Chagas (Boletim, 1948, p. 131), "a qual por não ter entenlligencia do Seo Idioma se faz difficultoza, mas não tanto, q'brevem ${ }^{\text {te }}$ não haja de baptisar alguns adultos além dos infantes" (Boletim, 1948, p. 130). A mistura étnica de brancos, índios e negros, pelo que consta dos exemplos transcritos, "estava na plenitude do acontecer, pela fecundidade das mulheres, parindo até mais de quatro filhos" (Boletim,
1948, p. 43); e) índios como os carijós eram partilhados como peças que se inventariavam no rol de bens familiares (Boletim, 1948, p. 105). Mas quando criados no "gremio da igreja, são forras e livertas segundo os Alvarás de Sua Magestade, [...] para poderem viver como tais" (Boletim, 1948, p. 107).

Ainda em relação aos índios, a "Provisão de Dom Phelipe Rey de Portugal dos Algarves daquém e dalém mar em África Senhor de Guiné e da Conquista" passada aos moradores de São Vicente, capitania do Brasil, determinava que "nenhuma pessoa rosse as terras dos Índios forros das Aldeyas de Piratininga dessa dita Capitania contra vontade dos ditos Índios forros, com pena de duzentos cruzados para cativos [...] Subscrita por Jerônimo Correa, 
escrivão". Essa Provisão, datada de 11 de outubro de 1580 , e expedida pelo capitão Hyeronimo Leytão, outorgava aos índios naturais de Piratininga "seis legoas de terra en quadra onde chamão Carapecuyba ao longo do Rio [Tieté] [... ] e outras seis legoas en quadra, comesando donde se acabão as terras que se derem a João Ramalho e Antonio de Macedo, que dizem que chegão até donde chamão Jaragua Pernahyba [Parnaíba]". Concedeu, portanto, Jerônimo Leitão a posse territorial preservada aos índios da terra (Boletim, 1945), representados pelos guaranis emigrados e remanescentes dos tupiniquins, autores da toponímia antiga de São Paulo: Rio de Inbuaçaba (Embuaçava, Emboaçava, Boaçava), Caucaia, Ybytãtã (Ubitãtã/Butantã), entre outros tantos (Boletim, 1945, pp. 57-60).

\section{INTERFERÊNCIAS LINGÜISTICAS, CÓDIGOS DE COMUNICAÇÃO}

Em oportunidade anterior (Dick, 1999), ao discutirmos a contribuição do léxico indígena e africano ao português brasileiro, trouxemos o entendimento de Mattoso Câmara a respeito da língua como fato histórico e às modificações introduzidas pelos sistemas em contato. Mattoso recupera conceitos de Sapir como os de "deriva lingüística", que utilizamos no sentido de evolução e mudanças, de flutuação e variação de formas e empréstimos de palavras. Os exemplos são os da língua geral amazônica, o nheengatu, em que a mudança de sentidoé determinada pelas novas práticas culturais adotadas. Assim, o sentido genérico específico de "roupa" (no tupi aoba) passa, no novo código, a compor-se ao de "camisa" / (a)Kamiša, "camisa minha", termo marcado pela relação destinador/ objeto. Isso o leva a concluir que as possibilidades de encontros são "irrestritas no âmbito lexical, mais nas palavras culturais, próprias de um povo e menos freqüentes na forma gramatical e fônica".

O português do Brasil, em sua trajetória americana, até constituir-se em língua nacional oficial, sofreu embates, principalmente quanto à natureza e à forma de incorporação vocabular. Os contatos imediatos foram feitos no próprio território, por via direta de transmissão. Tanto um grupo como o outro em presença, isto é, indígenas e africanos, são responsáveis por parcelas significativas de adstratos lingüísticos, dicionarizados, a maioria deles, como "brasileirismos", a recuperação do étimo, portanto,nem sempre se tornando fácil, pelo obscurecimento do sentido formador. A difusão do tupinambá e de suas matrizes lexicais por toda a costa foi a causa principal da ocorrência de tupinismos importantes no português brasileiro, muito embora Mattoso os vincule, de preferência, aos topônimos, em alguns campos semânticos, apenas. As pesquisas do Atesp e do ATB, no entanto, alargam o desempenho desses empréstimos, pelas possibilidades de inovação e incorporação de caracteres lexicais. Trata-se de um tema em aberto, pois esta é a natureza peculiar do léxico, ou seja, considerar válidos os referenciais motivadores, externos ao código.

Em nossas pesquisas, centramo-nos mais na língua tupi para apresentar alguns pontos de contato com o português, num sistema de interferência, por ser ela o idioma mais conhecido tantas as várias combinatórias resultantes. Há outras possibilidades linguiísticas de contato que, entretanto, não progrediram lexicalmente, no sentido de uso e frequiência: a própria situação geográfica dessas outras línguas, o encontro tardio em termos de um aprofundamento maior, quando a cartografia já estava pronta e bastante configurada, lingüisticamente, à maneira tupi, tudo concorrendo para essa transmissão em menor escala, o que não significa demérito algum para essas línguas.

Das línguas naturais do tronco makrojê, o bororo tem sido bastante estudado tanto antropológica quanto lingüisticamente. Alguns morfemas lexicais podem ser destacados pela sua presença mais constante nos conjuntos sígnicos. Tem-se, por exemplo, relativamente à água, os formantes po/ 
pobo; no tupi: y/paranálpará; aplicados indistintamente aos rios como às cidades nascentes em suas proximidades; /ri/ é a pedra, com o mesmo valor do /ita/ túpico; as cores que entram nos vocábulos, xoréu, "escuro"; ekureu, "amarelo", assim, poxoreu, “água escura”; pobo-ekureu, “água amarela”; no tupi paranájuba, “água amarela"; iuna, "rio escuro"; por exemplo. Sobre o nheengatu, que é a resultante da evolução do tupi colonial com acréscimos semânticos, morfofonêmicos e lexicais, ge- rados pelas interferências lingüísticas, o general Couto de Magalhães (1975, pp. 13-20) apresenta algumas ponderações metodológicas:

1) Paralelamente ao vocabulário das palavras lexicais, o autor introduz, nas Lições "Primeira" e "Segunda" do Curso de Língua Tupi Viva ou Nheengatu - Parte Prática, o verbo ter no absolutivo e formas interrogativa e negativa, apto a demonstrar, ainda que empiricamente, uma forma de diálogo, em frase curta:

\section{VOCABULÁRIO EM NHEENGATU}

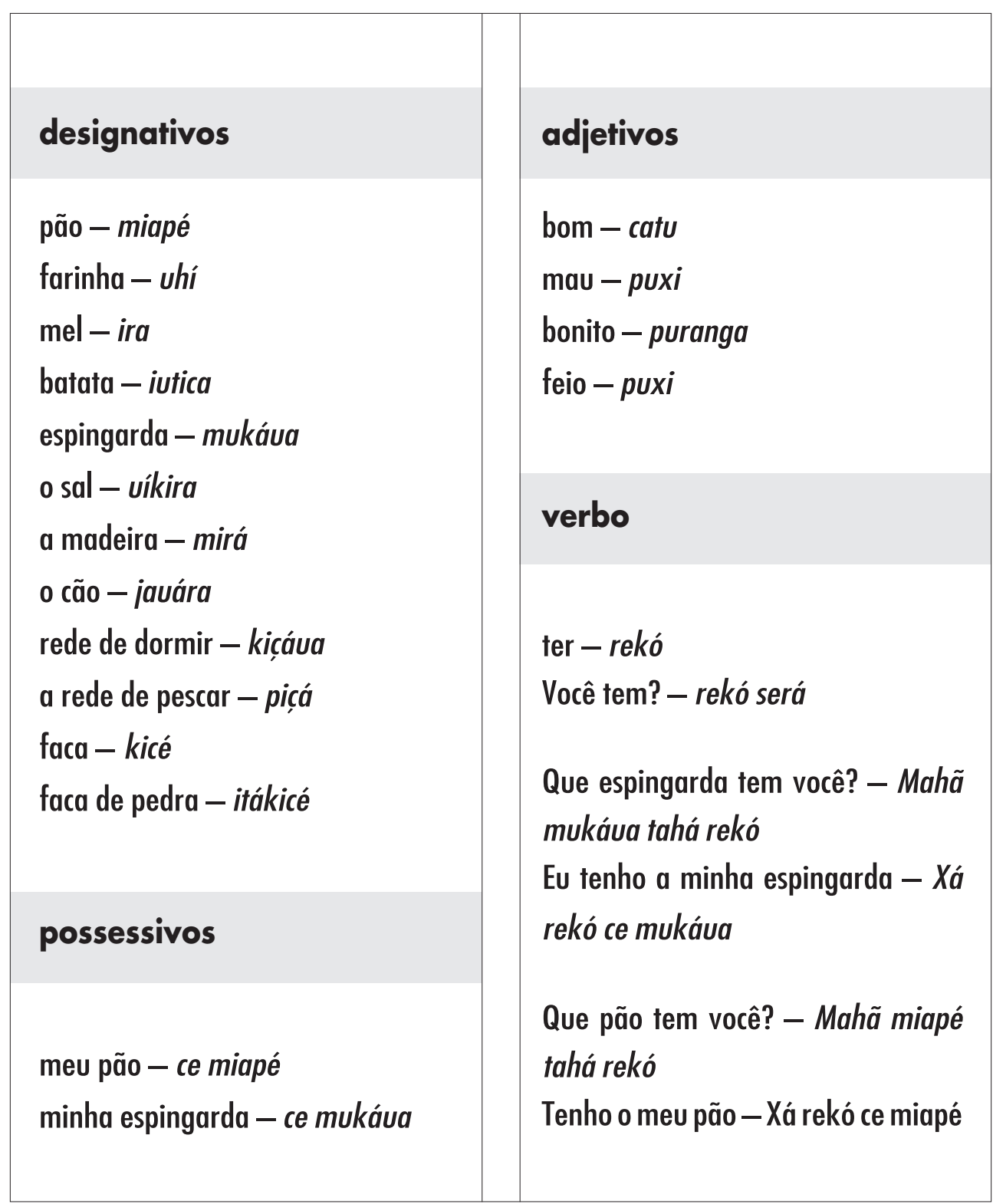


A estrutura vocabular do nheengatu oitocentista, de base colonial tupi, com introdução de empréstimos culturais (espingarda, pão) e representação fonêmica modificada em determinadas posições silábicas, mostra as conseqüências ou decorrências do papel que exerce, ainda, na comunidade amazônica atual, no alto Rio Negro, em São Gabriel da Cachoeira. Como língua de comunicação entre falantes de procedência diversa, aproxima-se do entendimento de língua franca regional, de contato, a princípio não-nativa de nenhuma das comunidades envolvidas. Não se generalizando para além da área de ocorrência estudada, constitui-se em bolsões significantes, que passam como marcas identitárias, se não de um povo, pelo menos de um processo histórico diferenciado, cuja base não foi a língua oficial do país, a transplantada.

Em outra ocasião (Dick, 1999) dissemos também que o nheengatu, sem ser uma língua étnica, própria de grupos por herança materna propriamente dita, representa a consciência de ser um código de expressão válido para diversos falantes. "Poderia até traduzir uma fase de pidginização, resultante do cruzamento de duas línguas anteriores, o português e o tupinambá, uma vez que, em sua organização, os vestígios de ambos os sistemas estão presentes. São formas peculiares do dizer amazônico em que se nota a adoção de vocábulos portugueses com fonêmica própria e, em muitos casos, com mudanças de sentido: 'trovão' (PB / trovã (LG); 'vassourinha' / vaçuriya; 'vender'/ vendera; 'brilhar' / wera (beraba, tupi); 'estrela' / yacitá (iacitatá, tupi); 'cunhada' / kuyada; 'dinheiro' / diyiru; 'tecido' / kamixá (aoba, tupi); 'vagalume' / gagaluna; 'restinga' / iwaté (ibaté, tupi)".

Para Rodrigues (1993,p.96), entretanto, o entendimento é diferente, quando diz que as línguas indígenas brasileiras "não se desenvolveram como pidgins nem como crioulos, mas são continuações de línguas indígenas que passaram a ser faladas pelos mestiços de homens europeus e mulheres índias". Uma vez "eliminados os índios,os mestiços passaram a ser os únicos falantes da língua original e os transmissores dela a outros índios e outros europeus [...]. Esse processo terá andado paralelamente à formação de uma cultura cabocla, luso-indígena".

A partir desse ponto de vista, compreende-se a sua intervenção no que chamou de língua geral paulista, da fase mameluca do tupi/tupinambá colonial, em que essa forma de expressão convivia e certamente até sobrepujava o português na fala.

\section{CONCLUSÃ̃}

O general Couto de Magalhães, por ocasião do tricentenário do padre Anchieta, em 1897, pronunciou uma conferência alusiva à data (1975, p. 141), em que pede licença ao público para iniciá-la com as próprias palavras do homenageado:

"Por isso vós me permitireis que eu comece esta conferência saudando-vos como o Padre José de Anchieta saudava os piratininguaras (indigenismo de base tupi, 'moradores de Piratininga') ou paulistas de 1560 , na língua paulista que eles falavam naquele tempo e que alguns de nós ainda hoje falam, dizendo-vos: 'Tupã omogaraíba, yawé ára catú omehê pee me’. O que na língua dos portugueses quer dizer: 'Deus vos abençoe (Tupã omogaraíba) e vos dê tempos felizes (ára catú)'”.

No entanto, as Atas da Câmara da vila e da própria cidade, nos volumes pesquisados, são omissas quanto à fala do povo. Não registram essas possíveis realizações, mesmo nos discursos dos camaristas, a não ser na toponímia, conforme nosso levantamento (Dick, 1997).

Cabe-nos, portanto, buscar o contraponto a que a memória da terra, em alguns de seus contornos, quem sabe nos direcionará. 


\section{BIBLIOGRAFIA}

ALMEIDA, Antonio Paulino de. "Memória História de Cananéia", in Revista de História, vol. XXVI, n. 49, ano XIII. São Paulo, FFLCH-USP, 1962.

ANCHIETA, Padre Joseph de. Informação do Brasil e de suas Capitanias (1584). Introdução de Leonardo Arroyo. São Paulo, Obelisco, 1964.

A Arte de Gramática da Língua mais Usada na Costa do Brasil. Salvador, Universidade Federal da Bahia, 1980.

ATAS da Câmara da Vila / Municipal / da Cidade de São Paulo. Vol. I (1562-96); Vol. 9IX (1720-29); Vol. XX20 (1797-809); Vol. XXVII (1832-351834); Vol. LXIII63 (1877). São Paulo, Prefeitura do Município de São Paulo / Sub-Divisão e Documentação Histórica / Departamento de Cultura.

ATAS do Pile II - Programa Interamericano de Lingüística e Ensino de Idiomas. São Paulo, FFLCH- USP, 1979.

BOLETIM CVI n. 17. Etnografia e Língua Tupi-guarani. Oraçães e Diálogos da Doutrina Cristã na Língua Brasílica. Ms Século XVIII. Transcrito e anotado por Plínio Ayrosa. São Paulo, FFCL-USP, 1950.

BOLETIM do Departamento do Arquivo do Estado de São Paulo, vol. V, maço 2 - Tempo Colonial - 1721-1804. São Paulo, Publ. Globo, 1945.

BOLETIM do Departamento do Arquivo do Estado de São Paulo, vol. VIII, maço 2 - Tempo Colonial - 1721-1804. São Paulo, Publ. Globo, 1948.

CARDIM, Padre Fernão. Tratados da Terra e Gente do Brasil. Introdução de Rodolfo Garcia. Belo Horizonte/São Paulo, Itatiaia/Edusp, 1980.

CARTAS e Datas de Terra. Vol. XI. São Paulo, Prefeitura do Município de São Paulo/Sub-Divisão e Documentação Histórica/Departamento de Cultura, 1833 a 1835.

DICK, Maria Vicentina de Paula do Amaral. Motivação Toponímica: Princípios Teóricos e Modelos Taxionômicos. Tese de Doutorado. São Paulo, FFLCH-USP, 1980.

. Toponímia e Antroponímia no Brasil. Coletânea de Estudos. 2ae ed. São Paulo, Serviço de Artes Gráficas da Faculdade de Filosofia, Letras e Ciências Humanas-USP, 1990.

"Atlas Toponímico: um Estudo de Caso", in Acta Semiotica et Lingvistica, vol. 6. São Paulo, 1996, pp. 27-44.

. A Dinâmica dos Nomes na Cidade de São Paulo - 1554-1897. 2a ed. São Paulo, Annablume, 1997.

. "Contribuição do Léxico Indígena e Africano ao Português do Brasil", in Anais do Congresso Internacional de Lusitanistas. Rio de Janeiro, 1999 (http://www.geocities.com/ail_br/contribuicao dolexicoindigena.html, acessado em outubro de 2004).

DRUMMOND, Carlos. Vocabulário na Língua Brasílica. 2 vols. São Paulo, FFLCH-USP, 1952-53.

EDELWEISS, Frederico G. Estudos Tupis e Tupi-guarani: Confrontos e Revisões. Rio de Janeiro, Brasiliana, 1969.

ELIA, Sílvio. A Língua Portuguesa no Mundo. São Paulo, Ática, 1998.

FRANC,A, Ernesto. Chrestomathía da Língua Brasílica. Leipzig, 1859.

FURLAN, Osvaldo Antônio. Influência Açoriana no Português do Brasil em Santa Catarina. Florianópolis, Ed. da UFSC, 1989.

GALVÃ0, Eduardo. "Estudos sobre a Aculturação dos Grupos Indígenas do Brasil”, in Revista de Antropofagia, vol. 50, no 1. São Paulo, FFLCH-USP, 1957.

GRENAND, Françoise; FERREIRA, Epaminondas Henrique. Pequeno Dicionário da Língua Geral. Manaus, Seduc/Núcleo Rec. Tecnol., 1989.

GUIZZETTI, Germán Fernández. "La Etnolinguistica: del Mundo del Idioma al Mundo de la Cultura", in Revista de Antropologia, vol. 5, n. 1. São Paulo, FFLCH-USP, 1957. 
. "Proyecciones Filosóficas de Algunas Teorias Etnolingüísticas Contemporâneas (4ํ․ Parte)", in Revista de Antropologia, vol. 12, n. 1 e 2. São Paulo, FFLCH-USP, 1964.

LYNCH, Kevin. La Imagen de la Ciudad. Buenos Aires, Ediciones Infinito, 1976.

MAGALHÃES, General Couto de. O Selvagem. Edição em Comemoração do Centenário. Contém o prefácio da segunda edição revista pelo sobrinho do autor. Prefácio da presente edição: Vivaldi Moreira. Belo Horizonte/São Paulo, Edusp/Itatiaia, 1975.

MARCOY, Paul. Viagem pelo Rio Amazonas. Tradução, introdução e notas de António Porro. Manaus, Editora Governo Estadual do Amazonas/Secretaria do Estado da Cultura, Turismo e Desporto/Editora da Universidade do Amazonas, 2001.

MELLO, Heliana Ribeiro de. "Português Padrão, Português Não Padrão e a Hipótese do Contato Lingüístico", in Tânia Maria Alkmin (org.). Para a História do Português Brasileiro. São Paulo, Humanitas/FFLCH-USP, 2002 (Vol. III: Novos Estudos).

MONTES GIRALD0, José Joaquim. “El Español de Colômbia”, in Thesaurus, XXXVII. Bogotá, 1982.

PETRONE, Pasquale. Aldeamentos Paulistas. São Paulo, Edusp, 1995.

REIS, Paulo Pereira dos. O Indígena do Vale do Paraíba. São Paulo, Coleção Paulística/Gov. do Estado de São Paulo, 1979

RODRIGUES, Aryon Dall'Igna. Línguas Brasileiras: para o Conhecimento das Línguas Indígenas. São Paulo, Edições Loyola, 1993.

SALA, Marius. El Problema de las Linguas em Contacto. México, Universidade Autónoma de Mexico, 1988.

SAMPAIO, Teodoro. 0 Tupi na Geografia Nacional. São Paulo, Nacional, 1987.

SOUZA, Gabriel Soares de. Tratado Descritivo do Brasil em 1587. São Paulo, Nacional/Editora da Universidade de São Paulo, 1971.

VIOTTI, Padre Helio Abrandos. "S. J. Anchieta e o IV Centenário de Pinheiros", in Revista de História, vol. XXIV, no 49, ano XIII. São Paulo, FFLCH-USP, 1962. 